Revista lus et Praxis, Año 17, No 2, 2011, pp. 231 - 282

ISSN 0717 - 2877

Universidad de Talca - Facultad de Ciencias Jurídicas y Sociales

"Armonización de los derechos de autor en la comunidad andina:

hacia un nuevo régimen común"

Alberto Cerda Silva

\title{
ARMONIZACIÓN DE LOS DERECHOS DE AUTOR EN LA COMUNIDAD ANDINA: HACIA UN NUEVO RÉGIMEN COMÚN*
}

\author{
COPYRIGHT HARMONIZATION IN THE ANDEAN COMMUNITY: \\ THROUGH A NEW COMMON REGIME
}

\begin{abstract}
Alberto Cerda Silva ${ }^{* *}$
RESUMEN

La Comunidad Andina, cuyo origen se remonta a finales de los sesenta, es uno de los principales procesos de integración latinoamericana, el cual actualmente involucra a Bolivia, Colombia, Ecuador, y Perú. En 1993, como parte del proceso de integración de las economías que conforman la Comunidad, ésta adoptó la Decisión 351 que establece un régimen común en materia de derechos de autor y conexos para sus países miembros. Dicho régimen constituyó un primer paso en la armonización normativa de los países que integran la Comunidad, los que aún preservaron la facultad de adoptar reglas en materia de derechos autorales, en tanto éstas no infringiesen las disposiciones de la Decisión.

Sin embargo, el transcurso de los años, los desafíos de las nuevas tecnologías, y el emergente bilateralismo, entre otras causas, han erosionado la eficacia del régimen común como instrumento de armonización normativa en la Comunidad Andina. Al mismo tiempo, las significativas diferencias en el derecho interno de los países miembros, aun cuando toleradas por el régimen común, obstruyen el adecuado funcionamiento del mercado interno, particularmente en el contexto de la economía de la información. Estas circunstancias hacen explícita la necesidad de actualizar el régimen común a fin de facilitar la integración de los países de la Comunidad Andina.

El presente artículo describe brevemente la Decisión 351, para luego analizar las

principales limitaciones del régimen común vigente a efectos de identificar los problemas que requieren una urgente solución normativa en la Comunidad Andina. Enseguida, se sugieren algunos de los temas sobre los cuales la Comunidad Andina
\end{abstract}

* Una versión preliminar de este artículo fue presentada en el Seminario "Trade and Integration in the Americas" dirigido por los profesores Mario A. Umaña, José Rivas-Campo y César Parga, en Georgetown University Law Center, el otoño del 2011. El autor desea expresar su agradecimiento al último de ellos por sus valiosos comentarios y sugerencias a versiones preliminares de este artículo. El autor desea asimismo agradecer a la Comisión Fulbright y a la Comisión Nacional de Ciencia y Tecnología (de Chile), por su apoyo para la realización del Programa de S.J.D. en Georgetown University Law Center, en el marco del cual tuvo la ocasión de escribir este artículo. Trabajo recibido el 26 de julio y aprobado el 25 de octubre 2011.

** Licenciado en Ciencias Jurídicas y Sociales, Universidad de Chile; Magíster en Derecho Público, Universidad de Chile; LL.M. in International Legal Studies, Georgetown University; Profesor en Derecho Informático, Facultad de Derecho de la Universidad de Chile. Correo electrónico: acerda@uchile.cl. 
debería poner énfasis al actualizar el régimen común -estos son, la extensión de los derechos de autor, limitaciones y excepciones, dominio público, y observancia de los derechos de propiedad intelectual-, así como algunas estrategias para alcanzar dicha armonización normativa.

\section{ABSTRACT}

The Andean Community, which started late in the sixties, is one of the main processes of integration in Latino America, that currently involves Bolivia, Colombia, Ecuador, and Peru. In 1993, as part of the process of integration, the Andean Community adopted the Decision 351 that sets forth a common regime on copyright and neighboring rights. That regime was a first step in the legal harmonization on that matter for those countries, which still preserve their domestic law, in so far as it does not infringe the provisions of the Decision.

However, the efficiency of the common regime as an instrument for harmonization within the Andean Community has been reduced because of the course of the years, challenges of new technologies, and emerging bilateralism, among other causes. At the same time, even when tolerated by the common regime, significant differences between the domestic law of country members obstacle the proper functioning of the internal, particularly en el context of digital economy. Those circumstances made explicit the need for updating the common regime in order to facilitate the integration of the Andean Community.

This article describes briefly the Decision 351, and then analyzes the main limitations of the in force common regime in order to identify the issues that require an urgent legal harmonization within the Andean Community. Then, this article suggests some those issues on which the Andean Community must emphasize its harmonization when updating the common regime-copyright scope, exceptions and limitations, public domain, and copyright enforcement- and makes some recommendations on strategies to achieve that legal harmonization.

PaLABRAS CLAVE

Derechos de Autor, Comunidad Andina, Régimen Común

KEY WORDS

Copyright, Andean Community, Common Regime

\section{INTRODUCCIÓN}

La Comunidad Andina, inicialmente conocida como Pacto Andino, es un proceso de integración que tiene lugar en Latinoamérica desde 1969 con la suscripción del Acuerdo de Cartagena, por Bolivia, Colombia, Chile, Ecuador y Perú1. En 1973, Venezuela también adhirió a la Comunidad. Durante las décadas de los setenta y ochenta, con la salvedad de haberse creado instituciones comunitarias, existió escaso progreso en este proceso de integración regional, debido a la prevalencia de dictaduras en la región y a su incompatibilidad con

1 Acuerdo de Cartagena, Bogotá, de 28 de mayo de 1969, enmendado por el Protocolo de Trujillo, de 10 de marzo de 1996. 
las medidas nacionales de política económica; este fue el caso de Chile, que en 1976 abandonó la Comunidad².

A comienzos de los noventa, una vez que gobiernos democráticos se habían instalado nuevamente en la región y se había superado la crisis económica, el proceso de integración dentro de la Comunidad Andina se revitalizó ${ }^{3}$. En esos años, diversas medidas contribuyeron a crear un área de libre comercio, mediante la reducción arancelaria, la armonización de los procedimientos aduaneros, y la liberalización del comercio en bienes, el transporte y las telecomunicaciones. Además, como parte de dicha intensificación, la Comunidad Andina adoptó una normativa común en diversas áreas, tales como inversión extranjera, empresas comunitarias, propiedad industrial e intelectual ${ }^{4}$. De hecho, en 1993, la Comunidad Andina adoptó la Decisión 351 que establece un régimen común en derechos de autor y conexos (en lo sucesivo, Decisión 351 o la Decisión)

Como un primer paso en el proceso de convergencia en materia de derechos autorales, la Decisión constituyó una iniciativa destacada y ambiciosa, que efectivamente contribuyó a la armonización normativa de los países de la Comunidad Andina ${ }^{6}$. Sin embargo, las peculiaridades del derecho interno de los países miembros, los desafíos de las nuevas tecnologías, y el emergente bilateralismo, entre otras causas, han socavado el rol de la Decisión en la armonización de los derechos de autor en la Comunidad. Dicha falta de armonización puede transformarse en un serio problema en el proceso de integración en curso, especialmente en el contexto de la economía de la información, al obstaculizar el adecuado funcionamiento del mercado interno.

Existe abundante literatura acerca del proceso de integración conducido por la Comunidad Andina ${ }^{7}$. Sin embargo, su armonización normativa en materia de

\footnotetext{
2 Véase Vela Orbegozo, Bernardo, La Integración Regional como un Factor de Desarrollo Nacional, en Reformas y Políticas en Colombia y América Latina, Universidad Externado de Colombia - CIPE, 2003, pp. 289-308; Fuentes FernándeZ, Alfredo, "Contexto Histórico y Avances de la Integración en la Comunidad Andina", Revista Oasis, Universidad Externado de Colombia, № 13, 2008, pp. 177-196.

3 Véase O'KeEFE, Thomas Andrew, "How the Andean Pact Transformed Itself into a Friend of Foreign Enterprise", International Lawyer Vol. 30, 1996, pp. 818 et seq.

${ }^{4}$ Véase supra nota 2.

5 Decisión № 351 Régimen Común sobre Derecho de Autor y Derechos Conexos, adoptada por la Comisión del Acuerdo de Cartagena, el 17 de diciembre de 1993, Gaceta Oficial de la Comunidad Andina № 145, 21 de diciembre de 1993.

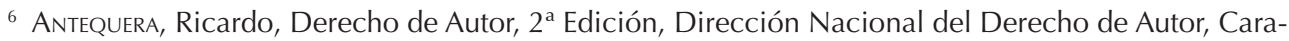
cas - Venezuela, 1998, pp. 935-936.

7 Véase Secretaría General de la Comunidad Andina, 40 Años de Integración Andina: Avances y Perspectivas, en Revista de la Integración, № 4 - Junio 2009; O'KeEFE, Thomas Andrew, Latin American and Caribbean Trade Agreements: Keys to a Prosperous Community of the Americas, Martinus Nijhoff Publishers, Países Bajos, 2009, pp. 243-302. Véase Brewer-Carías, Allan-Randolph (Ed.), Derecho Comunitario Andino, Fondo Editorial Pontificia Universidad Católica del Perú, Lima, 2003.
} 
derechos autorales permanece desconocido. En Estados Unidos, por ejemplo, los autores se han concentrado en el significativo rol que cumple el Tribunal de Justicia de la Comunidad Andina en la litigación y la observancia de los derechos de propiedad intelectual ${ }^{8}$. En Latinoamérica, los autores han evitado un análisis crítico del régimen común en materia de derechos de autor, limitándose a efectuar meras descripciones de él y muy ocasionales críticas al mismo ${ }^{9}$. Este artículo, en cambio, hace sólo una breve descripción de la Decisión 351, analiza luego las principales limitaciones del régimen común vigente a efectos de identificar los temas que requieren una urgente convergencia normativa en la Comunidad Andina y, finalmente, sugiere algunas estrategias para alcanzar dicha convergencia.

Analizar los desafíos de la regulación de los derechos autorales en el contexto del proceso de integración regional es útil para delinear la futura agenda de trabajo dentro de la Comunidad Andina. Es verdad que durante la última década la integración entre sus países miembros ha permanecido estancada, pero en los recientes años es posible apreciar una atmósfera política más distendida entre los países de la región andina, la consolidación de gobiernos democráticos, y el crecimiento de las economías de la región, todo lo cual puede contribuir a revitalizar una vez más el proceso de integración. Además, este análisis puede proveer experiencia a otros procesos de integración regional en curso en Latinoamérica, tal como la Unión de Naciones Suramericanas que

\footnotetext{
${ }^{8}$ Véase Rodríguez Lemmo, María Alejandra, "Study of Selected International Dispute Resolution Regimes, with an Analysis of the Decisions of the Court of Justice of the Andean Community", Arizona Journal of International and Comparative Law Vol. 19, 2002, pp. 863-929 (describiendo en detalle el tribunal y sus principales decisiones); Helfer, Laurence R.; Alter, Karen J., "The Andean Tribunal of Justice and Its Interlocutors: Understanding Preliminary Reference Patterns in the Andean Community", New York University International Law and Politics Vol. 41 2009, pp. 871-930 (describiendo la relación entre el tribunal andino y las autoridades y tribunales de los países miembros, y reportando que el $97 \%$ de los casos decididos por el Tribunal de Justicia de la Comunidad Andina se refieren a propiedad intelectual); Rodríguez Yong, Camilo A., "Enhancing Legal Certainty in Colombia: the Role of the Andean Community", Michigan State Journal of International Law Vol. 17, 2008-2009, pp. 407-463 (analizando el rol del Tribunal de Justicia de la Comunidad Andina proveyendo certeza jurídica a los inversionistas en la región andina); Helfer, Laurence R.; Alter, Karen J.; y Guerzovich, M. Florencia, "Islands of Effective International Adjudication: Constructing an Intellectual Property Rule of Law in the Andean Community", American Journal of International Law Vol. 103, 2009, pp. 1-47 (sosteniendo que el Tribunal de Justicia de la Comunidad ha contribuido a crear "rule-of-law" en materia de propiedad intelectual en la Comunidad Andina). Véase también Leathley, Christian, International Dispute Resolution in Latin America: An Institutional Overview, Kluwer Law International, Alphen aan den Rijn, 2007, pp. 107127 (describiendo el arreglo institucional de la Comunidad Andina, especialmente la competencia de su Tribunal de Justicia).

9 Véase, e.g., ANTEQuera, Ricardo, "Copyright and Andean Community Law", Revue Internationale du Droit D'Auteur Vol. 166, 1995, pp. 56-127; y, PACÓN, Ana María, "La Protección del Derecho de Autor en la Comunidad Andina", en Brewer-Carías, Allan-Randolph (Ed.), Derecho Comunitario Andino, Fondo Editorial Pontificia Universidad Católica del Perú, Lima, 2003, pp. 299-324.
} 
haría converger las economías de la Comunidad Andina, el Mercado Común del Sur (MERCOSUR), Chile, Guyana, y Suriname ${ }^{10}$.

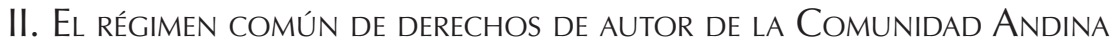

Hacia finales de los años ochenta, la Comunidad Andina carecía de un régimen uniforme de protección para las creaciones intelectuales y artísticas ${ }^{11}$. Las diferencias entre los compromisos internacionales de cada uno de los países miembros de la Comunidad evidenciaba las significantes diferencias entre sus niveles de protección. Bolivia, Colombia y Ecuador eran parte de la Convención Interamericana de Derechos de Autor ${ }^{12}$. Un instrumento que provee un nivel de protección más bajo que aquél previsto en el Convenio de Berna ${ }^{13}$. Colombia y Ecuador, así como Venezuela y Perú, eran partes de la Convención Universal de Derechos de Autor ${ }^{14}$, un instrumento diseñado para proveer un nivel de protección intermedio y hacer las veces de puente hacia el Convenio de Berna ${ }^{15}$. Colombia, Perú y Venezuela habían adherido también al Convenio de Berna, si bien los últimos aún requerían implementar éste en sus disposiciones de derecho interno ${ }^{16}$.

Las diferencias significativas entre la protección a los derechos de autor al interior de la Comunidad Andina acarreaba problemas para el adecuado funcionamiento del mercado interno. Una potencial solución era la armonización normativa. Así, en 1991 se dio inicio a trabajos preparativos, los que fueron interrumpidos a la espera de la adopción de nuevas leyes por Bolivia y Venezuela ${ }^{17}$;

${ }_{10}$ Véase Tratado constitutivo de la Unión de Naciones Suramericanas, hecho en Brasilia - Brasil, el 23 de mayo de 2008. Disponible En: http://www.comunidadandina.org/unasur/tratado_constitutivo. htm [visitado el 13/07/2011]

11 Antequera, Copyright, cit. nota n. 9, pp. 56-127, pp. 62-65; Antequera, Derecho, cit. nota n. 6, pp. 913-915.

12 Convención Interamericana sobre el Derecho de Autor en Obras Literarias, Científicas y Artísticas, adoptada en Washington D.C., el 22 de junio de 1946.

13 Lipszrc, Delia, "Esquema de la Protección Internacional del Derecho de Autor por las Convenciones del Sistema Interamericano", en Lipszyc, Villalba \& Uchtenhagen, La Protección de los Derechos de Autor en el Sistema Interamericano, Universidad Externado de Colombia, Dirección Nacional de Derechos de Autor, Bogotá, 1998, p. 33 .

${ }^{14}$ Convención Universal sobre Derecho de Autor. Ginebra, 6 de septiembre de 1952.

15 Lipszyc, Delia, Copyright and Neighbouring Rights, UNESCO Publishing, Paris, 1999, pp. 604605, 751; Antequera, Ricardo, El Nuevo Derecho de Autor en Venezuela, Autoralex, Caracasa, 1994, p. 572.

16 Véase Anexo: Tabla 1: Comunidad Andina de Naciones, acuerdos internacionales sobre derechos de autor en que sus miembros son partes.

17 Antequera, Copyright, cit. nota n. 9, pp. 56-127, pp. 62-67; Antequera, Derecho, cit. nota n. 6, pp. 913-914. 
siendo reasumidos en $1993^{18}$. A finales de tal año, sobre la base de un reporte elaborado por un comité de expertos ${ }^{19}$. la Comisión, el órgano legislativo de la Comunidad Andina ${ }^{20}$, adoptó la Decisión 351 que fijó el régimen común sobre derechos de autor y conexos. Para entonces, además, todos los países miembros de la Comunidad Andina habían ratificado tanto la Convención Universal como el Convenio de Berna ${ }^{21}$.

La Decisión 351 es derecho comunitario y supranacional, con efectos directos e inmediatos sobre las autoridades comunitarias y locales de los países miembros $^{22}$. A diferencia de las directivas de la Unión Europea, las decisiones comunitarias no requieren implementación en el derecho interno de los países miembros de la Comunidad Andina, porque ellas tienen efectos obligatorios inmediatos y prevalecen sobre el derecho interno de tales países. Con todo, las decisiones comunitarias permiten la subsistencia del derecho interno, siempre que éste no contravenga a aquéllas ${ }^{23}$; como resultado de ello, los países miembros de la Comunidad Andina pueden modificar su derecho interno a efectos de evitar confusión, pero no es necesario para efectos de implementación. Excepcionalmente, las decisiones comunitarias admiten "un complemento legislativo de parte del derecho interno" ${ }^{\prime 24}$; el cual, como este artículo explicará, es requerido, alentado o permitido en varias disposiciones de la Decisión 351.

La Decisión fue concebida como un primer paso en el proceso de convergencia normativa en materia de derechos de autor entre los países miembros de la Comunidad Andina, el cual requeriría una profundización ulterior ${ }^{25}$. La Decisión impuso reglas de trato nacional hacia los creadores, reconoció cier-

\footnotetext{
18 Ibídem. Véase también, PAcón, La Protección, cit. nota n. 9, p. 300.

19 Antequera, Derecho, cit. nota n. 6, p. 915.

20 Artículos 6 y 7 Decisión 236 Codificación del Acuerdo de Cartagena, adoptada por la Comisión del Acuerdo de Cartagena, el 26 de mayo de 1969, Gaceta Oficial de la Comunidad Andina No 31, 26 de julio de 1988.

21 Véase, Anexo: Tabla 1: Comunidad Andina de Naciones, acuerdos internacionales sobre derechos de autor en que sus miembros son partes.

22 Tremolada Álvarez, Eric, "El Derecho Andino: Una Sistematización Jurídica para la Supervivencia de la Comunidad Andina de Naciones", Cuadernos Constitucionales de la Cátedra Fadrique Furió Ceriol N 57, Universidad de Valencia, España, pp. 35-75; Rondón de SAnsó, Hildegard, El Régimen de la Propiedad Industrial, Caracas, 1995, pp. 86-87.

23 Véase también, Salones Gaite, Ana María, La Propiedad Intelectual en Bolivia: Marco Conceptual, Jurídico e Institucional, 2003, p. 100 (reclamando de la incertidumbre jurídica suscitada por la duplicidad normativa del derecho interno y comunitario); ANTEQUera, Ricardo y FerreYros, Marysol, El Nuevo Derecho de Autor en el Perú, Peru Reporting, Lima, 1996, p. 34.

24 TremoladA, El Derecho, cit. nota n. 22, p. 49.

25 Antequera, Copyright, cit. nota n. 9, pp. 56-127, pp. 66-67; AnTEQuera, Derecho, cit. nota n. 6, p. 915.
} 
tos derechos patrimoniales y morales, fijó la vigencia mínima de los mismos, estableció ciertas excepciones y limitaciones a los derechos de autor, resolvió la protección del software y las bases de datos, y adoptó algunas medidas para garantizar la observancia de los derechos autorales, entre otras. En los casos en que la normativa interna de los países miembros resulte inconsistente con las disposiciones de la Decisión, estas últimas prevalecen a partir de su entrada en vigencia ${ }^{26}$. En consecuencia, aun siendo un primer avance, la Decisión forzó la conformación de un régimen común en matera de derechos de autor.

La Decisión preservó un amplio margen de maniobra para la adopción de normas de derecho interno por los países miembros, en tanto ellas no fuesen inconsistentes con la disposiciones de la primera. De hecho, la Decisión hace continuas remisiones a su desarrollo en derecho interno. Así, por ejemplo, tratándose de obras por encargo ${ }^{27}$, droit de suite ${ }^{28}$, cómputos de plazos de protección ${ }^{29}$, cesión y licenciamiento ${ }^{30}$, y afiliación a entidades de gestión colectiva ${ }^{31}$, entre otras. En otros casos, la Decisión omite el tratamiento de determinados aspectos de la regulación autoral, relegando ellos a su desarrollo por derecho interno, tales como las normas sobre procedimientos, medidas cautelares y sanciones criminales. Todavía más, en varios casos la Decisión se ha limitado a establecer un estándar mínimo, dejando en libertad a la normativa interna de los países miembros para ir más allá del estándar previsto en ella; este es el caso de los derechos morales reconocidos a los autores ${ }^{32}$, los derechos patrimoniales exclusivos ${ }^{33}$, el plazo de protección de las obras ${ }^{34}$, y las excepciones y limitaciones a los derechos de autor ${ }^{35}$.

\footnotetext{
${ }^{26}$ Véase, e.g., TRibunal de Justicia de LA Comunidad ANDina, Caso 64-IP-2000, Decisión final, 6 de septiembre de 2000, pp. 2-5 (resolviendo que el derecho comunitario es obligatorio para actores públicos y privados de la Comunidad y de cada país miembro, que tiene efectos directos dentro del derecho interno de estos últimos, y que prevalece sobre cualquier regulación interna); y, Corte ConstITUCIONAL DE Colombia, Caso 155/98, Claudia Blum de Barberi y otros, Decisión final, 28 de abril de 1998, ๆ 19 (sosteniendo que el derecho comunitario es prevalente y tiene aplicación preferente sobre el derecho interno de los países miembros de la Comunidad Andina).

27 Artículo 10 Decisión 351.

28 Artículo 16 Decisión 351.

29 Artículo 19 Decisión 351.

30 Artículo 30 Decisión 351.

31 Artículo 44 Decisión 351.

32 Artículo 12 Decisión 351.

33 Artículo 17 Decisión 351.

34 Artículo 18 Decisión 351.

35 Artículos 21 y 22 Decisión 351.
} 
La remisión al derecho interno de los países partes parece haber sido el principal mecanismo empleado durante las negociaciones para superar la falta de acuerdo en determinados temas ${ }^{36}$. Desafortunadamente, esta técnica normativa, basada en la remisión al derecho interno, la omisión en el régimen común, y la fijación de meros estándares mínimos ha socavado la aspiración de lograr un nivel de convergencia satisfactorio dentro de la Comunidad Andina, lo cual se ha agravado con el curso de los años, según veremos.

La Decisión 351 fue preclara y ambiciosa a la hora de determinar su contenido. Sus disposiciones anticiparon significativamente el contenido del Acuerdo sobre los Aspectos de los Derechos de Propiedad Intelectual relacionados con el Comercio (Acuerdo sobre los ADPIC) ${ }^{37}$. Así, por ejemplo, en lo tocante a la protección de software y bases de datos ${ }^{38}$. De hecho, la Decisión facilitó la prácticamente inmediata accesión a la Organización Mundial de Comercio por todos los países miembros de la Comunidad Andina ${ }^{39}$, dada la consistencia entre las disposiciones de la Decisión y del Acuerdo sobre los ADPIC ${ }^{40}$. La convergencia normativa producida por el régimen común fue impresionante, comparada con el cauteloso proceso de armonización seguido por la Unión Europea, que ha requerido de la adopción e implementación de varias directivas comunitarias para abordar algunos de los temas resueltos por la Decisión ${ }^{41}$. Si bien, el cauto y gradual proceso de la Unión Europea ha permitido una mejor articulación

\footnotetext{
${ }^{36}$ Véase Antequera, Derecho, cit. nota n. 6, pp. 920-923 (mencionando la falta de acuerdo en derechos morales, importaciones paralelas, droit de suit, plazos de protección, y excepciones); ANTEQUERA, Ricardo, "El Derecho de Autor y los Derechos Conexos en la Legislación Venezolana", en ANTEQuera, Ricardo y Gómez Mucl, Gineli, Legislación sobre Derecho de Autor y Derechos Conexos, Ed. Jurídica Venezolana, Caracas, 1999, p. 23 (mencionando la falta de acuerdo en torno a las obras por encargo durante la negociación de la Decisión 351).

${ }^{37}$ Acuerdo sobre los Aspectos de los Derechos de Propiedad Intelectual relacionados con el Comercio (ADPIC), 15 de abril de 1994, Acuerdo de Marrakech que establece la Organización Mundial de Comercio, Anexo 1C, 1869 U.N.T.S. 299. Véase también ANTEQUERA, Copyright, cit. nota n. 9, pp. 94-95 (mencionando que los redactores de la Decisión sacaron ventaja del trabajo hecho a efectos de adoptar un protocolo adicional para el Convenio de Berna).

38 Artículos 23-27 Decisión 351 en relación con artículo 10 y 11 Acuerdo sobre los ADPIC.

39 Véase Anexo: Tabla 1: Comunidad Andina de Naciones, acuerdos internacionales sobre derechos de autor en que sus miembros son partes.

${ }^{40}$ Gómez Velasco, Xavier, Patentes de Invención y Derecho de la Competencia Económica, Universidad Andina Simón Bolívar, Quito, 2003, p. 17; Rodrícuez Ruiz, Marco, Los Nuevos Desafíos de los Derechos de Autor en Ecuador, Universidad Andina Simón Bolívar, Quito, 2007, pp. 48-49.

${ }^{41}$ Véase Comisión EuROPEA, Documentos sobre Derechos de Autor. En: http://ec.europa.eu/internal_market/copyright/documents/documents_en.htm [visitado el 19/07/2011].
} 
entre sus miembros, tanto en su contenido como en su desarrollo, ${ }^{42}$ así como un trámite legislativo más transparente.

\section{LIMITACIONES DEL RÉGIMEN COMÚN SOBRE DERECHOS DE AUTOR}

El régimen común generado a partir de la Decisión 351 significó un progreso significativo en la protección de los derechos de autor y en la armonización legislativa de los países miembros de la Comunidad Andina ${ }^{43}$, sin embargo, él no está exento de críticas. Tal como es explicado más adelante, el régimen común ha sido incapaz de remover diferencias de derecho interno que confieren ventajas comparativas injustas a los productores de un país miembro respecto de otro, ocasionando distorsión en el funcionamiento del mercado interno. En cambio, la Decisión confirió unilateralmente ventajas a terceros países en desmedro del mercado interno. Adicionalmente, el régimen común no sólo no resolvió, sino que en ciertos casos agravó los obstáculos para el libre flujo de bienes aun entre los mismos países miembros. Peor aún, varias de las disposiciones contenidas en el régimen común han erosionado la capacidad de los países de la Comunidad Andina para desarrollar políticas públicas tendentes a promover el interés público.

Otras limitaciones del régimen común han quedado de manifiesto más recientemente, a raíz de las negociaciones de acuerdos de libre comercio o simplemente del desarrollo tecnológico. Por un lado, el régimen común ha sido insuficiente para hacer frente a las subsecuentes negociaciones bilaterales en materia de propiedad intelectual por parte de los países miembros de la Comunidad Andina. ${ }^{44}$ Por otro lado, el régimen carece de disposiciones para hacer frente a los desafíos de las nuevas tecnologías, particularmente la digitalización de las obras y la creciente penetración de Internet. Estas dos limitaciones, como se explica más adelante, se han hecho evidentes en la regulación de las medidas de protección tecnológicas y en el régimen de responsabilidad de los prestadores de servicio en línea.

Esta sección considera con mayor detenimiento las limitaciones del régimen común, el contexto legal en el cual tienen lugar, y su efecto para los países

\footnotetext{
${ }^{42}$ Véase Kur, Annette, "Intellectual Property", en van Empel, Martijn, From Paris to Nice: Fifty Years of Legal Integration in Europe, Kluwer Law International, La Haya, 2003, p. 85 et seq.

43 Véase Pacón, La Protección, cit. nota n. 9, pp. 299-324.

${ }^{44}$ Forero, Fabio, "La Coordinación de la Política Comercial en la Comunidad Andina y su Efecto en el Proceso de Integración", Revista de la Asociación Iberoamericana de Academias, Escuelas e Institutos Diplomáticos, N 1, Madrid, 2010, pp. 29-30. En: http://segib.org/colaboraciones/2010/ 10/05/ revista-de-la-asociacion-iberoamericana-de-academias-escuelas-e-institutos-diplomaticos/ [visitado el 19/07/2011] (argumentando que las negociaciones de los tratados de libre comercio reflejan la incapacidad de los países miembros de la Comunidad Andina para actuar en conjunto y, en cambio, si para adoptar flexibilidades que permiten a sus miembros negociar individualmente con terceros países).
} 
miembros de la Comunidad Andina. El análisis es ilustrado con situaciones que hacen evidente un inapropiado funcionamiento del mercado interno. Este último es un concepto extensamente usado en la literatura sobre derecho de la integración en la Unión Europea ${ }^{45}$. Un mercado común requiere del libre movimiento de bienes y servicios, así como de personas y capital ${ }^{46}$. A efectos de obtener un mercado común es necesario remover las barreras artificiales y armonizar las políticas nacionales para garantizar un adecuado funcionamiento del mercado interno ${ }^{47}$. Una de dicha barreras no arancelarias pueden ser los derechos de propiedad intelectual, pues su marcado carácter territorial puede entrar en conflicto con un mercado común, por ejemplo, cuando legítimos bienes (o servicios) son exportados a un país en el cual ellos son ilegales ${ }^{48}$. De hecho, en el proceso de integración de la Unión Europea, tal como debería de ser el caso de la Comunidad Andina, la armonización de los derechos de propiedad intelectual ha sido "vital" para el mercado interno, porque ellos pueden afectar el "libre movimiento de bienes y la preservación de una competencia sin distorsiones" 49 .

Para obtener un adecuado funcionamiento del mercado común no es necesario una completa uniformidad normativa en propiedad intelectual o en derechos autorales. Un mercado común requiere sí la remoción de las barreras legales que bloquean el libre movimiento de bienes y servicios protegidos por los derechos de autor, distorsionando su funcionamiento, distrayendo comer-

\footnotetext{
45 Véase, e.g., DE VRIES, Sybe Alexander, Tension within the Internal Market: The Functioning of the Internal Market and the Development of Horizontal and Flanking Policies, Europa Law Publishing, Groningen, 2006; NIC SHUIBHNE, Niamh (Ed.), Regulating the Internal Market, Edward Elgar Publishing, Cheltenham, 2006; Chalders, Demian; Davies, Gareth; y Monti, Giorgio, European Union Law, 2nd ed., Cambridge University Press, 2010, pp. 674-711.

46 Compárese artículo 26 (1) y (2) Versión consolidada del Tratado de Funcionamiento de la Unión Europea, Diario Oficial de la Unión Europea, 30 de marzo de 2010 (disponiendo que "1. La Unión adoptará las medidas destinadas a establecer el mercado interior o a garantizar su funcionamiento, de conformidad con las disposiciones pertinentes de los Tratados. 2. El mercado interior implicará un espacio sin fronteras interiores, en el que la libre circulación de mercancías, personas, servicios y capitales estará garantizada de acuerdo con las disposiciones de los Tratados".), con el artículo 1 del Acuerdo de Cartagena (estableciendo los objetivos de la Comunidad Andina, entre ellos "facilitar su participación en el proceso de integración regional, con miras a la formación gradual de un mercado común latinoamericano").

47 Scott, Andrew, "Theories of Regional Economic Integration and the Gloval Economy", en Jackie

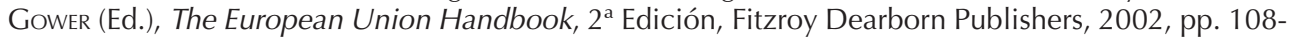
110 (distinguiendo entre una integración negativa y otra integración positiva del mercado común).

48 Colston, Catherine y Galloway, Jonathan, Modern Intellectual Property Law, 3 Edición, Routledge, 2010, pp. 13-16. Véase también DAVIES, Gareth, EU Internal Market Law, 2 Edición, Cavendish Publishing, Londres , 2003, pp. 185-195.

49 Kaczorowska, Alina, European Union Law, 2 Edición, Routledge, 2011, p. 489.
} 
cio, y creando competencia deslea ${ }^{50}$. Las necesidades de un mercado común son, hasta cierto punto, contingentes porque ellas dependen del progreso en la conformación y perfeccionamiento del mercado. Basados en tal análisis, esta sección sustenta la necesidad de incrementar la convergencia normativa en materia de derechos de autor en la Comunidad Andina.

\section{El régimen común no evita la distorsión en la competencia al interior del mercado interno: libros y software}

El adecuado funcionamiento del mercado al interior de la Comunidad Andina requeriría disponer de una mayor armonización en la normativa interna de los países miembros. Sin embargo, la normativa comunitaria tolera ${ }^{51}$, e incluso alienta $^{52}$, ciertas diferencias en la legislación interna de los países miembros, lo cual redunda en un inadecuado funcionamiento del mercado al proveer ventajas comparativas a los proveedores de un país sobre los de otros miembros de la Comunidad Andina. Así acontece, por ejemplo, en el rubro editorial y de desarrollo de programas computacionales.

El régimen común reconoce ciertos derechos como exclusivos del titular de los derechos de autor ${ }^{53}$, pero admite que los países miembros puedan reconocer derechos adicionales ${ }^{54}$. Por ejemplo, la Decisión reconoce que la distribución de obras puede tener lugar tanto por medios onerosos como $\mathrm{no}^{55}$, pero pareciera limitar el derecho exclusivo de autor al primer $\operatorname{caso}^{56}$. Sin embargo, dada la flexibilidad provista por la Decisión 351 a los países miembros de la Comunidad Andina, Colombia ha extendido el derecho exclusivo de autor al préstamo no oneroso de las obras ${ }^{57}$. De hecho, a diferencia del aparente numerus clausus de derechos exclusivos reconocidos por la Decisión a los titulares de derechos,

\footnotetext{
50 Antequera; Ferreyros, El Nuevo, cit. nota n. 23, p. 33; Antequera, Derecho, cit. nota n. 6, p. 70.

51 Véase supra notas 27-31 y el texto que las acompaña.

52 Véase supra notas 32-35 y el texto que las acompaña.

53 Artículo 13 Decisión 351. Véase también, PAcóN, La Protección, cit. nota n. 9, p. 316.

54 Artículo 17 Decisión 351.

55 Artículo 3 Decisión 351 (definiendo "distribución al público" como "Puesta a disposición del público del original o copias de la obra mediante su venta, alquiler, préstamo o de cualquier otra forma").

56 Artículo 13 c) Decisión 351 (disponiendo que "El autor o, en su caso, sus derechohabientes, tienen el derecho exclusivo de realizar, autorizar o prohibir: ... c) La distribución pública de ejemplares o copias de la obra mediante la venta, arrendamiento o alquiler"). Véase también, ANTEQuera; FERrEYROS, El Nuevo, cit. nota n. 23, p. 137 (clarificando que la Decisión limita los derechos exclusivos de distribución a las transferencias con fines de lucro, excluyendo aquéllas a título gratuito).

57 Dirección Nacional de Derecho de Autor - Colombia, Concepto 1-2005-4826, 9 de marzo de 2005 (rechazando la existencia de una excepción para el préstamo bibliotecario de libros), y Concepto 2-2010-4800, 30 de noviembre de 2010 (rechazando la existencia de una excepción para el préstamo bibliotecario de material audiovisual).
} 
el derecho colombiano reconoce a los titulares de derechos el control sobre cualquier posible uso de las obras ${ }^{58}$. Este comprensivo alcance de los derechos de autor, que algunos autores estiman consistente con la tradición europea del "droit d" auteur" la Comunidad Andina ${ }^{60}$. En cambio, otros países han reconocido un limitado número de derechos exclusivos, como Bolivia ${ }^{61}$.

Editores y escritores de algunos países de la Comunidad Andina pueden disfrutar de ciertas ventajas comparativas con respecto a sus pares de los restantes países. En Colombia, por ejemplo, bibliotecas y establecimientos educacionales deben pagar por los préstamos bibliotecarios de libros, porque el derecho interno garantiza a los titulares de derechos autorales el control total sobre el uso de las obras y no existe una excepción a favor de bibliotecas e instituciones educativas ${ }^{62}$. En cambio, en Perú si bien la protección es total, la ley prevé una

\footnotetext{
58 Corte Constitucional de Colombia, C-276/96, caso María Teresa Garcés Lloreda, Decisión final, 20 de junio de 1996 (considerando que "Los derechos patrimoniales de autor, en la concepción jurídica latina, son tantos como formas de utilización de la obra sean posibles, ellos no tienen más excepciones que las establecidas por la ley, pues las limitaciones han de ser específicas y taxativas). Véase también, Dirección Nacional de Derecho de Autor - Colombia, Concepto 1-2006-4988, 1 de abril de 2006 y Concepto 1-2008-8704, 29 de abril de 2008 (sustentando la protección comprensiva de los derechos patrimoniales). La protección comprensiva de los derechos autorales a toda eventual explotación económica de la obra ha sido también articulada a nivel comunitario. Véase Tribunal de Justicia de La Comunidad Andina, Caso 24-IP-98, Decisión final, 25 de septiembre de 1998, p. 3 (decidiendo en un caso acerca de protección de los derechos autorales en software que "El derecho patrimonial es de contenido ilimitado, razón por la cual su titular o titulares están facultados para autorizar cualquier forma de explotación de la que pueda ser objeto el programa de ordenador").

59 Antequera, Ricardo, "El Derecho de Autor y los Derechos Conexos en el ALCA: Una Visión Panorámica de las Negociaciones", en Braga Avancinı, Helenara y Leão Barcellos, Milton Lucídio, Perspectivas Autorais do Direito da Propriedade Intelectual, EdiPUCRS, Puerto Alegre - Brasil, 2009, pp. 23-24 (sosteniendo que la adopción de una protección comprensiva de los derechos patrimoniales de autor y un limitado reconocimiento de las excepciones constituye un "triunfo" de la tradición del derecho civil, en el contexto de las fallidas negociaciones del Acuerdo de Libre Comercio de las Américas). Véase también, PACón, La Protección, cit. nota n. 9, p. 302 (sosteniendo que la Decisión adoptó la tradición del derecho civil europeo en materia de derechos autorales).

${ }^{60}$ En Perú, véase Antequera y Ferreyros, El Nuevo, cit. nota n. 23, pp. 127-128, 155, y 177 (sustentando una protección comprensiva de los derechos patrimoniales sobre la base de lo previsto en los artículos 31 (f), 37, y 50 de la Ley sobre Derechos de Autor del Perú). En Venezuela, ex miembro de la Comunidad Andina, véase ANTEQuerA, Ricardo, El Derecho, cit. nota n. 36, pp. 25-28 (sustentando la protección comprensiva de los derechos patrimoniales con base en los artículos 23 de la Ley de Derechos de Autor de Venezuela, y 18 de su reglamento).

${ }^{61}$ Artículo 15 Ley No 1322 de 1992: Ley de Derecho de Autor, Gaceta Oficial, 27 de abril de 1992 (Bolivia).

${ }^{62}$ Véase supra notas 58-60 y el texto que las acompaña.
} 
excepción que permite el préstamo público de las obras ${ }^{63}$, mientras en Bolivia no se reconoce a los titulares de derechos un derecho exclusivo para controlar el préstamo público, lo cual permite el préstamo de libros por bibliotecas sin necesidad de solicitar autorización alguna ${ }^{64}$. Además de crear un inapropiado funcionamiento del mercado editorial interno, tal asimetría es injusta, pues priva a una significativa parte de la población de los países miembros de la Comunidad Andina de servicios básicos que proveen acceso a la cultura y oportunidades de desarrollo ${ }^{65}$.

La Decisión 351 refleja el estándar de protección de los derechos de autor acorde a la realidad de comienzos de los años noventa, por ende, no toma en consideración el desarrollo vertiginoso de las tecnologías de la información, particularmente la digitalización de las obras ni la Internet. La ausencia en el régimen común de disposiciones al respecto confiere amplitud a los países miembros para adoptar normas en su derecho interno, en tanto no colisionen con las del régimen común. A consecuencia de ello, la distorsión en el funcionamiento del mercado interno se ha agravado, ya que las diferencias en el derecho interno de unos países miembros con otros confieren ventajas comparativas en diversas áreas, especialmente aquellas vinculadas a las tecnologías de la información, tales como la creación de productos multimedia, la prestación de servicios en línea ${ }^{66}$, y el desarrollo de programas computacionales.

Por ejemplo, el régimen común provee protección a los programas de ordenador y algunas excepciones a ello. En efecto, la Decisión 351, anticipándose al Acuerdo sobre los $\mathrm{ADPIC}^{67}$, reconoce expresamente que los programas de ordenador, tanto en su código fuente como objeto ${ }^{68}$, son protegidos por derechos de autor ${ }^{69}$. La Decisión autorizó también la generación de copias de respaldo, de las copias necesarias para el funcionamiento mismo del programa ${ }^{70}$, y la

\footnotetext{
${ }^{63}$ Véase artículos 31 f) y 43 f) Decreto Legislativo № 822: Ley sobre Derechos de Autor, Diario Oficial, 24 de abril de 1996 (Perú).

${ }^{64}$ Artículo 15 Ley No 1322 de 1992: Ley de Derecho de Autor, Gaceta Oficial, 27 de abril de 1992 (Bolivia).

65 Véase CHON, Margaret, "Copyright and capability for education: an approach 'from below'", en Wong, Tzen y DutfielD, Graham (Ed.), Intellectual Property and Human Development: Current Trends and Future Scenarios, Cambridge University Press, 2011, pp. 218-249 (refiriéndose a la severa carencia de libros en países en desarrollo y sustentando la necesidad de adoptar políticas públicas que provean acceso al conocimiento, incluyendo cambios en el régimen de los derechos autorales).

${ }^{66}$ Véase infra notas 222-231 y el texto que las acompaña.

67 Artículo 10 (1) Acuerdo sobre los ADPIC.

${ }^{68}$ Artículo 23 (1) Decisión 351.

${ }^{69}$ Artículo 4 I) Decisión 351.

70 Artículos 24-26 Decisión 351.
} 
modificación de él para fines personales. ${ }^{71}$ Dichas provisiones de la Decisión han sido reproducidas en el derecho interno de los países miembros de la Comunidad Andina ${ }^{72}$, con la salvedad de Colombia que sólo ha reglamentado la inscripción registral de dichos programas ${ }^{73}$. En consecuencia, la Decisión ha provisto un mínimo común estándar para la protección de programas computacionales por derechos de autor; pero los países miembros de la Comunidad Andina están autorizados a adoptar normas adicionales, en tanto ellas sean consistentes con el régimen común.

A través de los años, la evaluación de la normativa interna de los países miembros de la Comunidad Andina ha incrementado las diferencias en relación a la regulación de los programas computacionales. Dichas diferencias son particularmente importantes respecto del desarrollo por encargo y las excepciones para hacer uso del programa sin autorización ni pago al titular de los derechos sobre él. Al respecto, ni Colombia ni Bolivia ${ }^{74}$ han ido más allá de las excepciones ya disponibles en el régimen interno, pero los otros miembros de la Comunidad sí lo han hecho. Por ejemplo, de conformidad con el Acuerdo sobre los $\mathrm{ADPIC}^{75}$, Ecuador ha reconocido una excepción para el arrendamiento, cuando el programa computacional no es el objeto esencial del arriendo, tal como cuando se arrienda un vehículo que trae incorporado un programa computacional en su sistema ${ }^{76}$. Este también es el caso de Perú ${ }^{77}$. Sin embargo, Perú también ha reconocido, en términos similares a los de la Unión Europea ${ }^{78}$ y los Estados Unidos ${ }^{79}$, una excepción específica que permite

\footnotetext{
71 Artículo 27 Decisión 351.

${ }^{72}$ Artículos 15 y 16 Decreto Supremo № 24582 del 25 de abril de 1997: Reglamento del Soporte Lógico o Software (Bolivia); artículo 30 Ley de Propiedad Intelectual, codificación 2006-013, Boletín Oficial, 19 de mayo de 1998 (Ecuador); artículos 73 - 75 Decreto Legislativo No 822: Ley sobre Derechos de Autor, Diario Oficial, 24 de abril de 1996 (Perú).

73 Decreto № 1360 de 23 de Junio de 1989: Por el cual se reglamenta la inscripción del soporte lógico (software) en el Registro Nacional del Derecho de Autor, Diario Oficial, 21 de marzo de 1995 (Colombia).

${ }^{74}$ Véase supra notas 72-73 y el texto que las acompaña.

75 Artículo 11 Acuerdo sobre los ADPIC.

${ }^{76}$ Artículo 31 Ley de Propiedad Intelectual, codificación 2006-013, Boletín Oficial, 19 de mayo de 1998 (Ecuador).

77 Artículo 72 Decreto Legislativo No 822: Ley sobre Derechos de Autor, Diario Oficial, 24 de abril de 1996 (Perú).

78 Artículo 6 Directiva 2009/24/CE del Parlamento Europeo y del Consejo de 23 de abril de 2009 sobre la protección jurídica de programas de ordenador, Diario Oficial de la Unión Europea, $L 111$, 5 de mayo de 2009.

79 Sega Enterprises Ltd. v. Accolade, Inc. 977 F.2d 1510 C.A.9 (Cal.),1992. 20 de octubre de 1992.
} 
la ingeniería inversa de software a efectos de obtener la interoperabilidad de un programa independiente ${ }^{80}$.

El reconocimiento de una excepción para la ingeniería inversa de software, a efectos de obtener la interoperabilidad en el desarrollo de programas independientes, confiere ventajas competitivas a las empresas de desarrollo peruanas. En efecto, en los restantes países de la Comunidad Andina las empresas desarrolladoras de software están legalmente obligadas a contratar licencias de desarrollo con proveedores de software privativo -tales como Microsoft y Apple- a efectos de desarrollar programas de ordenador interoperables ${ }^{81}$. En cambio, Perú permite a dichas empresas prescindir de licencias y les autoriza por ley a hacer ingeniería inversa, esto es, descompilar el código objeto de un programa, destilar el código fuente, y a partir de él desarrollar programas computacionales compatibles con éste. En términos simples, las empresas desarrolladoras de software en Perú pueden ahorrarse los usualmente altos costos de licenciamiento y acceder técnicamente al código de programación de un software a efectos de desarrollar soluciones compatibles con él.

Esto crea un inapropiado funcionamiento del mercado interno de los servicios de desarrollo de software, pues las compañías de un país disfrutan de ventajas que se basan en meras barreras legales. Para superar tal funcionamiento puede sugerirse que una excepción para ingeniería inversa sea extendida a todos los países de la Comunidad Andina.

\section{El régimen común provee unilateralmente ventajas competitivas} a terceros países en desmedro del mercado interno: trato nacional y restablecimiento de derechos

El principio de trato nacional es esencial para efectos de lograr el florecimiento del comercio internacional. A través de tal principio, los Estados se obligan a no conferir a los bienes y servicios de origen extranjero un trato menos favorable de aquel que confieren a sus propios nacionales ${ }^{82}$. En materia de derechos de

80 Artículo 76 Decreto Legislativo No 822: Ley sobre Derechos de Autor, Diario Oficial, 24 de abril de 1996 (Perú).

${ }^{81}$ Véase Antequera y Ferreyros, El Nuevo, cit. nota n. 23, pp. 234-236. En contra, Grijalva, Agustín, "Copyright \& the Internet", en Bonilla, Marcelo y Cliché, Gilles (Ed.), The Internet and Society in Latin America and the Caribbean, International Development Research Center, Canadá, 2004, p. 324-325 (sustentando que la ingeniería inversa de software es "compatible" con los principios fundamentales de los derechos de autor y, consiguientemente, está ya permitida en la Comunidad Andina).

82 Véase artículo 3 Acuerdo General sobre Aranceles Aduaneros y Comercio de 1994, 15 de abril de 1994, Acuerdo de Marrakech por el que se establece la Organización Mundial del Comercio, Anexo 1A, 1867 U.N.T.S. 187 (1994); artículo 17 Acuerdo General sobre el Comercio de Servicios, 15 de abril de 1994, Acuerdo de Marrakech por el que se establece la Organización Mundial del Comercio, Anexo 1B, 1869 U.N.T.S. 183 (1994). 
autor, el principio ha tenido expreso reconocimiento en el Convenio de Berna ${ }^{83}$, así como en el Acuerdo sobre los ADPIC ${ }^{84}$. Los Estados se han obligado a no ejercer discriminación en la protección que se brinda a las creaciones cuyo origen se encuentra en otro país parte de dichos instrumentos internacionales. Sin embargo, el régimen común va más allá, concediendo unilateralmente protección a obras de origen extranjero en casos donde no era requerido por el derecho internacional ${ }^{85}$.

La Decisión 351 otorga protección a todos los creadores, incluso si el país de origen de las creaciones no protege a los nacionales de los países miembros de la Comunidad Andina ${ }^{86}$. Esto implica que, a la fecha de entrada en vigencia del régimen comunitario -el 21 de diciembre de 1993-, los países miembros de la Comunidad Andina extendieron su protección no sólo a los autores cuyos países de origen eran parte del Convenio de Berna, el instrumento internacional sobre derechos de autor líder de la época, sino también a autores de países que no eran entonces miembros de dicho convenio. Así, autores de países como Rusia, Corea, República Dominicana, El Salvador y más de medio centenar de otros países recibieron protección en la Comunidad Andina, a pesar de que los autores comunitarios no fuesen protegidos en dichos países ${ }^{87}$. Aun hoy, tras la masiva adherencia al Convenio de Berna por los países en desarrollo como resultado del Acuerdo sobre los $\mathrm{ADPIC}^{88}$, presumiblemente a cambio de acceso a mercado para sus productos agrícolas ${ }^{89}$, la Decisión 351 brinda protección a autores de cerca de una veintena de países, inclusive si éstos no proveen dicha protección a los autores comunitarios; así sucede con Angola, Irán, Irak, Mozambique, y Taiwán, entre otros ${ }^{90}$.

\footnotetext{
${ }^{83}$ Artículo 5 (1) Convenio de Berna.

${ }^{84}$ Artículo 3 Acuerdo sobre los ADPIC.

${ }^{85}$ Parga, César, "Intellectual Property Rights", en Salazar XiRInachs, José Manuel y Robert, Maryse (ed.), Toward Free Trade in the Americas, Washington, DC, USA, Brookings Institution Press, 2001, p. 218.

${ }^{86}$ Artículo 2 Decisión 351, el cual dispone que los países miembros de la Comunidad Andina otorgarán a los nacionales de otros países un trato no menos favorable que el concedido a sus propios nacionales. Esta disposición tiene reflejo en el derecho interno de los países miembros. Véase, e.g., artículo 5 (2) Ley de Propiedad Intelectual, codificación 2006-013, Boletín Oficial, 19 de mayo de 1998 (Ecuador).

87 Véase World Intellectual Property Organization, Berne Convention Contracting Parties, En: http:// www.wipo.int/treaties/en/ShowResults.jsp?lang=en\&treaty_id=15 [visitado el 20/07/2011].

${ }^{88}$ Véase World Intellectual Property Organization, Berne Convention Statistics, En: http://www.wipo. int/treaties/en/statistics/StatsResults.jsp?treaty_id=15\&lang=en [visitado el 19/07/2011].

${ }^{89}$ Véase Yu, Peter, "TRIPS and Its Discontents", Marquette Intellectual Property Law Review, Vol. 10, 2006, pp. 369-410 (revisando cuatro diferentes discursos que explican el origen del Acuerdo sobre los ADPIC y por qué los países en desarrollo son partes de él).

${ }^{90}$ Véase supra nota 87.
} 
Dada la falta de transparencia en la adopción de la Decisión $351^{91}$, no es claro por qué ésta proveyó protección a las obras de autoría extranjera más allá de lo exigido internacionalmente. Puede sugerirse que ello es consistente con la racionalidad del droit $d^{\prime}$ autore, pues los creadores merecen protección independientemente de sus países de origen ${ }^{92}$. Puede sugerirse también que los redactores de la Decisión temían a la competencia de los autores extranjeros, en el entendido de que las obras extranjeras no protegidas podrían sustituir a las obras locales ${ }^{93}$. Cualquiera sea la razón, no existe evidencia empírica de que preservando tan amplia protección para las obras extranjeras provea beneficio alguno al mercado interno de la Comunidad Andina; al contrario, esto socava el acceso a la obras por la población comunitaria y reduce las oportunidades de negocios para los editores comunitarios.

Todavía más, la Decisión 351 protege las creaciones de autores de terceros países, incluso si ellas no son protegidas en sus propios países de origen, y aun si tales países no brindan reciprocidad a los autores comunitarios. El caso más emblemático es el restablecimiento de derechos, esto es, el reingreso de obras de dominio público al privado ${ }^{94}$. Tratándose de obras que habían ingresado a dominio público por no haber cumplido con las formalidades para obtener su protección en un determinado país, particularmente por la falta de registro, la Decisión restableció los derechos ${ }^{95}$. Así, por ejemplo, una obra que nunca recibió protección en los Estados Unidos por haberse omitido su registro ${ }^{96}$, en cambio, goza de protección en la Comunidad Andina ${ }^{97}$, incluso si los autores comunitarios no gozan de un beneficio análogo en tal país ${ }^{98}$.

${ }^{91}$ PACÓN, La Protección, cit. nota n. 9, p. 300 (alegando respecto de la falta de información acerca del proceso a través del cual el comité de expertos redactó el borrador de la Decisión). Véase también, ANTEQUERA, Derecho, cit. nota n. 6, p. 915 (refiriéndose al rápido y cerrado proceso de adopción de la Decisión).

92 Antequera y Ferreyros, El Nuevo, cit. nota n. 23, pp. 61-62.

93 LIPSZYC, Delia, La Conferencia de Revisión de las Convenciones de Berna y Universal (Paris - Julio de 1971): Enfoque Argentino, CISAC, Buenos Aires, 1975, p. 44 (sustentando el argumento de que las obras extranjeras no protegidas sustituyen a las obras locales, en el contexto de rechazar la adopción de flexibilidades adoptadas por el Apéndice del Convenio de Berna a favor de países en desarrollo).

94 ANTEQUERA, Derecho, cit. nota n. 6, pp. 934, 1014, sustenta que la Decisión remedió la injusticia de dejar sin protección ciertas obras por la falta de registro que era exigida por la legislación local derogada.

95 Artículo 60 Decisión 351.

96 Estados Unidos adhirió al Convenio de Berna en 1988; antes de su ratificación e implementación en derecho interno, Estados Unidos proveía protección federal sólo si la obra había cumplido con varias formalidades previstas en la ley de derechos de autor, incluyendo su registro ante la Oficina de Derechos de Autor de la Biblioteca del Congreso. Véase Berne Convention Implementation Act of 1988, Pub. L. No 100-568, 102 Stat. 2853.

97 Véase Artículo 2 Decisión 351.

98 Véase $\$ 104$ U.S. Copyright Act, la cual adopta un sistema más restringido de restablecimiento de los derechos autorales, limitado a obras de autores extranjeros que no han ingresado a dominio pú- 
Afortunadamente, los efectos del restablecimiento de derechos concedido por la Comunidad Andina deben diluirse con el curso de los años, a medida que más países adhieren al Convenio de Berna y al Acuerdo sobre los ADPIC, los cuales rechazan la exigencia de formalidades y exigen brindar protección automática a las creaciones ${ }^{99}$. Con todo, el restablecimiento de los derechos, sumado a la extensión de los plazos de protección ${ }^{100}$, tiene un efecto persistente, cual es sustraer del dominio público un significativo número de obras por varias décadas. No es claro por qué la Decisión adoptó tan amplio restablecimiento de derechos; una hipótesis es que entre los redactores de ella existía cierta aversión al dominio público por la idea subyacente de la ineficacia económica de los bienes públicos ${ }^{101}$. Cualquiera sea la explicación, el restablecimiento de los derechos no sólo afecta el acceso a las obras por la población en general, sino que también entraba la labor creativa de los propios autores, y obstaculiza el quehacer de las industrias culturales ${ }^{102}$. En casos en los cuales antes la ley autorizaba el uso de las obras, ahora será necesario disponer de una autorización de parte del titular de los derechos restablecidos (y presumiblemente el pago de licenciamiento).

Naturalmente, la Decisión adoptó una medida de resguardo respecto de los afectados por el restablecimiento de los derechos. Consciente de los costos de privar de sus derechos a quienes confiaron en el dominio público para llevar adelante sus actividades, la Decisión previó que la restitución de derechos no afectaría a quienes adquirieron derechos con anterioridad a su entrada en vigencia, tales como la edición de contenidos de dominio público o la creación

blico en sus países de origen, siendo éste un país elegible, y adoptando resguardo a favor de terceros interesados, a través de un sistema de notificaciones. A pesar de tratarse de un sistema más restringido que el previsto en la Comunidad Andina, el sistema de restablecimiento de derechos estadounidense es hoy cuestionado ante la Corte Suprema, porque él afectaría la libertad de expresión al obstaculizar la ejecución pública de obras musicales con derechos restablecidos. Véase U.S. Supreme Court, Golan v. Holder 131 S.Ct. 1600 (Mem), 7 de marzo de 2011 (granting certiorari).

99 Artículo 5 (2) Convenio de Berna; y artículo 9 Acuerdo sobre los ADPIC.

100 Compárense artículo 7 Convenio de Berna y artículo 18 Decisión 351 (establecen un plazo mínimo de protección igual a la vida del autor más 50 años post mortem auctoris) con artículo 21 Ley 23 de 1982 sobre derechos de autor, Diario Oficial, 19 de febrero 1982 (Colombia) (extendiendo la protección a 80 años p.m.a.). Véase también artículos 80-81 Ley de Propiedad Intelectual, codificación 2006-013, Boletín Oficial, 19 de mayo de 1998 (Ecuador), artículo 52 Decreto Legislativo № 822: Ley sobre Derechos de Autor, Diario Oficial, 24 de abril de 1996 (Perú), y artículo 25 Ley sobre el Derecho de Autor, Gaceta Oficial, 1 de octubre de 1993 (Venezuela) (extendiendo la duración de los derechos de autor a la vida del autor más 70 años p.m.a.).

101 Véase World Intellectual Property Organization (WIPO), Scoping Study on Copyright and Related Rights and the Public Domain (prepared by Séverine Dusollier), CDIP/4/3/REV./STUDY/INF/1, 7 de mayo de 2010, p. 21.

102 Id. pp. 13-15. 
de obras derivadas a partir de aquél ${ }^{103}$. La única limitante a dicha salvaguardia es que los usos se refieran a actividades ya realizadas o en curso a la fecha de entrada en vigencia de la Decisión, esto es, no beneficia el uso posterior de las obras con protección restablecida. Aunque el resguardo adoptado por la Decisión mitiga el efecto de hacer pasar obras de dominio público al privado, ella no se hace cargo del mayor costo social y económico que implica el restablecimiento de los derechos de propiedad intelectual ${ }^{104}$.

Al adoptar un concepto amplio de trato nacional, al punto de proteger obras provenientes de países que no son parte del Convenio de Berna, y restablecer derechos para el caso de obras que habían pasado al dominio público, incluso si ellas no recibieron protección en sus países de origen y éstos no ofrecen una protección análoga a los creadores comunitarios, el régimen común proveyó unilateralmente ventajas competitivas a los autores y titulares de derechos de terceros países en desmedro de los usuarios, creadores, y editores de la Comunidad Andina. Mientras usuarios, creadores e industrias culturales comunitarias deben enfrentar el licenciamiento y pago de derechos de autor en relación con ciertas obras, terceros países pueden no estar obligados a asumir tales costos. Esto puede no afectar el adecuado funcionamiento del mercado interno, pero sí la competitividad de la Comunidad Andina en el mercado internacional, junto con socavar las oportunidades para el desarrollo de su población.

\section{El régimen común ha agravado ciertos obstáculos para el libre flujo de bienes: el agotamiento de derechos}

El régimen común fue diseñado como un primer paso en el proceso de aproximación normativa de los países miembros de la Comunidad Andina ${ }^{105}$. Por consiguiente, era previsible que él no resolviese todos los temas legales y dejase algunos para su determinación por el derecho interno de sus miembros. Las diferencias en el derecho interno de los países miembros de la Comunidad fueron toleradas o subestimadas por el régimen común ${ }^{106}$. Sin embargo, como se ha mencionado, importantes diferencias entre los países han incrementado los obstáculos para el libre flujo de bienes y servicios protegidos por los derechos de autor. Más aún, la Decisión 351 no sólo dejó ciertos temas sin resolver, en algunos casos la Decisión agravó los obstáculos al libre flujo de bienes y servicios protegidos por los derechos de autor tanto en el mercado interno como en el internacional.

\footnotetext{
103 Artículo 60 Decisión 351.

104 Véase supra notas 101-102 y el texto que las acompaña.

105 Véase supra nota 25 y el texto que le acompaña.

106 Véase supra notas 27-35 y el texto que las acompaña.
} 
Dos decisiones adoptadas por el régimen común acrecientan los antes mencionados obstáculos: la adopción del agotamiento nacional de los derechos y la concesión a los titulares de derechos de autor de un derecho exclusivo para autorizar o prohibir la importación de una obra protegida, sin limitaciones ${ }^{107}$.

De acuerdo al agotamiento del derecho, también conocido como doctrina de la primera venta en los Estados Unidos, una vez una obra o copia de una obra ha sido distribuida por su titular, la enajenación ulterior de la misma obra o copia no requiere autorización ni pago de derechos al titular de los derechos de autor ${ }^{108}$. El agotamiento del derecho constituye una limitación al derecho exclusivo de distribución, esto es, una excepción al monopolio en la comercialización de la obra ${ }^{109}$. A nivel nacional, el agotamiento del derecho permite la reventa de obras, así, por ejemplo, la venta de libros de segunda mano no requiere autorización ni pago de derechos adicionales. A nivel internacional, el agotamiento del derecho permite las denominadas importaciones paralelas, esto es, que un mismo bien sea provisto simultáneamente a través de dos o más canales de distribución legítimos. Al facilitar la circulación de los bienes, el agotamiento de derecho permite, entonces, una competencia más intensa entre los proveedores $y$, finalmente, precios más asequibles para los consumidores ${ }^{110}$.

El Acuerdo sobre los ADPIC reserva a la legislación interna de los países parte la cuestión del agotamiento de los derechos de propiedad intelectual ${ }^{111}$. En consecuencia, los países son libres de determinar si adoptan y cuán extensamente el agotamiento de los derechos de autor. En este último caso, el agotamiento puede quedar limitado al mismo país en que la obra se ha distribuido (nacional), a una serie de países cuyas economías se encuentran integradas (regional), o extenderse sin limitación alguna respecto de otros países (internacional). Cada una de las opciones precedentes implica un mayor grado de libertad en el flujo de bienes de un país a otro.

No existe un claro consenso en torno a la extensión con que el agotamiento de los derechos debe ser implementado en el derecho interno de los países $^{112}$. Algunos países han optado por un flujo internacional de los bienes

\footnotetext{
107 Artículo 13 c) y d) Decisión 351.

108 Véase Castro García, Juan David, "El Agotamiento de los Derechos de Propiedad Intelectual", Revista la Propiedad Inmaterial, № 13 (2009), pp. 253-282, pp. 256-258.

109 Véase Vega Jaramillo, Alfredo, Manual de Derecho de Autor, Dirección Nacional de Derecho de Autor, Bogotá, 2010, p. 42.

110 Ibídem.

111 Artículo 6 Acuerdo sobre los ADPIC. Véase United Nations Conference on Trade and Development (UnCTAD) e International Centre for Trade and Sustainable Development (ICTSD), Resource Book on TRIPS and Development, Cambridge University Press, 2005, pp. 104-107.

112 Véase UNCTAD e ICTSD, Resource, cit. nota n. 111, pp. 92-117.
} 
sin limitaciones sustentadas en el derecho de autor, este es el caso de Australiaa $^{113}$, Chile ${ }^{114}$ y Nueva Zelanda ${ }^{115}$. Varias decisiones de la Corte Europea de Justicia ${ }^{116}$, fundadas en el Tratado que establece la Unión Europea ${ }^{117}$, sostienen a lo menos el agotamiento regional de derechos entre los países miembros de la Unión; consiguientemente, los derechos de propiedad intelectual no pueden ser un pretexto para la fragmentación del mercado comunitario ${ }^{118}$. En Estados Unidos, la doctrina de la primera venta parece agotar los derechos de los titulares sólo domésticamente ${ }^{119}$; de hecho, recientemente la conocida cadena de retail Costco intentó sin éxito revertir ante la Corte Suprema una decisión adversa adoptada por una corte federal ${ }^{120}$, la cual restringió la importación al país de bienes protegidos por el derecho de autor sin la autorización del titular de los derechos para su comercialización en el mercado estadounidense ${ }^{121}$. No

113 Fitzgerald, Anne y Fitzgerald, Brian, Intellectual Property in Principle, Lawbook Co., Sydney, 2004, pp. 152 - 156; DreIER, Thomas, "Shaping a Fair International IPR-Regime in a Globalized World. Some Parameters for Public Policy", en Govaere, Inge y Ulırich, Hanns (Eds.), Intellectual Property, Public Policy, and International Trade, Peter Lang, Bruselas, p. 56.

114 Artículo 18 Ley No 17.336 sobre Propiedad Intelectual, modificada por la Ley № 20.435, Diario Oficial, 4 de mayo de 2010 (Chile).

115 Véase $\S \S 9(1)(d)$ y 16(1)(d) Copyright Act 1994 № 143 (as at July 07, 2010), (Nueva Zelandia).

116 Véase Corte Europea de Justicia, Deutsche Grammophon Gesellschaft v Metro, 8 de junio de 1971 (decidiendo que el libre movimiento de bienes dentro del mercado común está en conflicto con la prohibición de un Estado miembro de la Unión Europea sobre la venta de bienes protegidos por los derechos de autor inicialmente distribuidos dentro del territorio de otro país miembro). Véase también Corte Europea de Justicia, EMI Electrola v Patricia, 24 de enero de 1989; Corte Europea de Justicia, Musik-Vertrieb membran GmbH and K-tel International v GEMA, 20 de enero de 1981.

117 Véase artículos 34 y 35 Versión consolidada del Tratado de Funcionamiento de la Unión Europea, Diario Oficial de la Unión Europea, 30 de marzo de 2010.

118 Corte Europea de Justicia, Deutsche Grammophon Gesellschaft v Metro, 8 de junio de 1971, p. 12 (sostiene que "el aislamiento de los mercados nacionales, sería repulsivo a los propósitos esenciales del tratado, cual es la unidad de los mercados nacionales en un único mercado".).

119 Véase $\$ 109$ (a) U.S. Copyright Act, que codifica la doctrina de la primera venta.

120 Costco Wholesale Corp. v. Omega, S.A., 131 S.Ct. 565 (13 de diciembre de 2010) (emitiendo una decisión dividida respecto de si bienes protegidos por derecho de autor fabricados legalmente en el extranjero pueden o no ser importados a los Estados Unidos y vendidos sin autorización expresa del titular de los derechos).

121 Omega S.A. v. Costco Wholesale Corp. 541 F.3d 982 C.A.9 (Cal.), 2008. 3 de septiembre de 2008 (decidiendo qué bienes protegidos por derecho de autor producidos en el extranjero no pueden ser importados a los Estados Unidos y vendidos sin la autorización expresa del titular de los derechos). En cambio, Quality King Distributors Inc. v. L'anza Research Int., 523 U.S. 135 (1998) (decidiendo que los derechos se agotan, en cambio, cuando bienes producidos en Estados Unidos son exportados al extranjero por el titular de derechos y finalmente re-importados a los Estados Unidos sin su autorización). 
obstante, el caso Costco deja aun abierta la puerta para una decisión posterior de la Corte Suprema al respecto ${ }^{122}$.

La Comunidad Andina impuso la modalidad más restrictiva de agotamiento para sus países miembros: el agotamiento nacional de los derechos ${ }^{123}$. A diferencia de cuanto acontece con los prístinos términos del régimen común sobre propiedad industrial ${ }^{124}$, en derechos de autor la Decisión 351 establece que el titular tiene el derecho exclusivo para prohibir y autorizar la importación de copias hechas sin su autorización al territorio de cualquiera de los miembros de la Comunidad ${ }^{125}$. Dicha cláusula no ha sido suficiente para garantizar el agotamiento regional o internacional de los derechos, especialmente frente a la doctrina que brinda comprensiva protección a los derechos de autor. Esta última, basada en disposiciones de la Decisión y de derecho interno de los países miembros de la Comunidad, sostiene que los titulares tienen derecho sobre cualquier uso de las obras ${ }^{126}$. Como resultado, en los países de la Comunidad Andina existe sólo agotamiento nacional

122 La decisión de la Corte Suprema de los Estados Unidos por un empate de votos implica que el caso Costco es resuelto por" Affirmance by an Equally Divided Court", esto es, la resolución de la corte federal recurrida queda a firme, pero el cuestionamiento constitucional persiste como no resuelto, permitiendo que sea nuevamente llevado ante la Corte en un caso análogo.

123 Véase World Trade Organization, Trade Policy Review Body, Trade Policy Review Ecuador, Report by the Secretariat - Revision, WT/TPR/S/148/Rev.1, 25 de julio de 2005, pp. ix-x, p. 24 y p. 72 p. 209; World Trade Organization, Trade Policy Review Body, Trade Policy Review, Report by the Secretariat Bolivia, WT/TPR/S/154, 4 de octubre de 2005, p. ix, p. 22, y pp. 80-81, p. 221. Asimismo, véase WorLD Trade Organization, Trade Policy Review Body, Trade Policy Review, Report by the Secretariat - Colombia, WT/TPR/S/172, 18 de octubre de 2006, pp. x, p. 23. En contra, véase WorLd Trade Organization, Trade Policy Review Body, Trade Policy Review, Report by the Secretariat - Peru, WT/TPR/S/189, 12 de septiembre de 2007, pp. 61-62, p. 230. Véase también DiReCCión NaCional De DereCho de Autor - Colombia, Concepto 2-2005-6647, 14 de julio de 2005 (concluyendo que "la figura del agotamiento del derecho no se encuentra expresamente consagrada en nuestra legislación nacional o comunitaria..., bajo ese entendido, el titular de derechos patrimoniales goza de un poder amplio y general para controlar cualquier manifestación del derecho de distribución sobre su obra o ejemplares de la misma".); VEGA, Manual, cit. nota n. 109, pp. 42 - 43; ANTEQUeRA, El Derecho, cit. nota n. 59, pp. 28-29.

124 Artículos 54 y 158 Decisión Nº 486 Régimen Común sobre Propiedad Industrial, adoptada por la Comisión del Acuerdo de Cartagena, 14 de septiembre de 2000, Gaceta Oficial de la Comunidad Andina, 19 de septiembre de 2000 (adoptando agotamiento internacional de los derechos en materia de patentes y marcas comerciales). Véase también, Cordero Álvarez, Clara Isabel, "El Agotamiento de los Derechos de Propiedad Intelectual de Patentes y Marcas en material de Salud Pública a la luz de la OMC y la UE: Especial Referencia a la Jurisprudencia del TJCE sobre el Reenvasado", en Saberes, Universidad Adolfo X El Sabio, Vol. 3, 2005, p. 12; VÁsquez SANTAMARía, Jorge Eduardo, "El Agotamiento del Derecho de Marca", Opinión Jurídica julio-dic., año/vol. 6, num. 12, Universidad de Medellín, Medellín, 2007, pp. 123-137; Organización Mundial de LA Propiedad InteleCtual, Alcance y Limitaciones de los Derechos de Propiedad Industrial, OMPI/PI/SEM/BOG/02/1, 1 de julio de 2002, en Seminario de la OMPI para los Países Andinos sobre la Observancia de los Derechos de Propiedad Intelectual en Frontera, 10 al 11 de julio de 2002, pp. 10-11 pp. 44-46 y pp. 13-15 pp. 59-66.

125 Artículo 13 d) Decisión.

126 Véase supra notas 57-60 y el texto que las acompaña. 
de los derechos de propiedad intelectual y, consiguientemente, los titulares tienen el derecho exclusivo a controlar la importación de las obras a través de los países. Esta posición no ha estado exenta de críticas por parte de quienes sustentan que la Decisión consagra el agotamiento internacional ${ }^{127}$, especialmente porque ella menoscaba el libre flujo de bienes protegidos por los derechos de autor dentro de la propia Comunidad Andina ${ }^{128}$.

Todavía más impresionante es el modo a través del cual la Comunidad Andina adoptó el agotamiento nacional de los derechos, a través del otorgamiento a los titulares del derecho de autor de un irrestricto derecho exclusivo sobre la importación de las obras al territorio de los países miembros ${ }^{129}$. Esto implica una verdadera capiti diminutio de los países miembros de la Comunidad Andina, al desprivar a éstos del derecho a determinar el grado de agotamiento y trasladar la decisión a los titulares del derecho de autor.

Efectivamente, a diferencia de otros países, y yendo más allá de los derechos usualmente reconocidos en instrumentos internacionales ${ }^{130}$, la Comunidad Andina concedió a los titulares de derecho no sólo el derecho a controlar la publicación, comunicación y distribución de la obra, sino también el monopolio sobre la importación de una obra o sus copias $^{131}$. Esto implica que la simple adquisición de una obra no faculta a su dueño para sacarla del país, ni aun para que circule dentro de la propia Comunidad Andina ${ }^{132}$. Para estos

127 Véase MAdrid, Luis Ángel, Importaciones Paralelas (Agotamiento de los Derechos de Propiedad Intelectual), Centro Colombiano del Derecho de Autor, 2005. En: http://www.cecolda.org.co/index. php?option=com_content\&task=view\&id=42\&ltemid=40 [visitado el 15/05/2011]. En contra, CASTRO, EI Agotamiento, cit. nota n. 108, p. 276 (rechazando el agotamiento internacional con base en el principio in dubio pro auctoris previsto en el artículo 257 de la ley colombiana de derechos autorales); CHARRIA García, Fernando, Derecho de Autor en Colombia, Instituto Departamental de Bellas Artes, Cali, 2001, pp. 41-42; ANTEQuera, Derecho, cit. nota n. 6, p. 920 (lamentando la falta de consenso dentro de la Comunidad Andina para reconocer "expresamente" el derecho exclusivo para autorizar o prohibir las importaciones paralelas); y FuENTES, Fernando, Manual de los Derechos Intelectuales, Vadell Hermanos Editores, Caracas, 2006, p. 243 nota 288.

128 Véase Pacón, La Protección, cit. nota n. 9, pp. 319-320.

129 Artículo 13 d) Decisión 351.

130 Véase, artículos 8, 9, 11bis, 12, y 14 ter Convenio de Berna; artículos 9-11 Acuerdo sobre los ADPIC.

131 Artículo 13 d) Decisión 351.

132 En contra, PAcón, La Protección, cit. nota n. 9, pp. 299 - 324, p. 320 (sustentado que las exportaciones son permitidas por la Decisión, pero no la ulterior comercialización de los bienes exportados). Véase también Instituto Nacional de Defensa de la Competencia y de la Protección de la Propiedad INTELECTUAL - Perú, Resolución 0121-1998-ODA, 9 de julio de 1998 (admitiendo el agotamiento de los derechos a efectos de introducir un software al país para su uso, pero no para su comercialización). Esta interpretación en vez de denegar el agotamiento de los derechos, limita éste a la introducción de una obra de un país a otro para su uso personal y, por consiguiente, produce efectos similares, pues obstaculiza el libre flujo de bienes y servicios dentro del mercado interno. 
casos, el dueño de una obra o ejemplares de ella necesita, además, de una autorización especial del titular de los derechos de autor y eventualmente el pago de un precio.

El agotamiento nacional de los derechos y la concesión del mencionado derecho irrestricto y exclusivo de importación crean obstáculos al adecuado funcionamiento del mercado interno de la Comunidad Andina. Más allá de la real eficacia del agotamiento nacional de los derechos en el contexto de una economía digital ${ }^{133}$, dicho agotamiento genera trabas adicionales a la libre circulación de los bienes, posibilita la fragmentación de los mercados nacionales, y permite la discriminación de precios hacia los consumidores ${ }^{134}$.

4. El régimen común ha sido incapaz de satisfacer necesidades de interés público: dominio público, excepciones y limitaciones a los derechos de autor

La Decisión 351 es fiel reflejo de una regulación que se esfuerza desproporcionadamente por brindar protección a los titulares de derechos autorales, prestando escasa atención al interés público envuelto en la regulación. La Decisión concedió derechos a los titulares más allá de lo requerido en cualquier instrumento internacional, tal como el control sobre la importación de las obras y el agotamiento nacional de los derechos ${ }^{135}$, y la adopción de un trato nacional amplio que brinda protección incluso a creaciones que carecen de ella en sus países de origen ${ }^{136}$. Pero, además, la Decisión autorizó a los países miembros de la Comunidad Andina a incrementar aún más la protección en su derecho interno, mediante el reconocimiento de más derechos patrimoniales y morales de los previstos en el régimen común ${ }^{137}$, y la extensión adicional del término de protección ${ }^{138}$. En cambio, la Decisión hizo escasos avances en la armonización de las normas sobre dominio público y fue notoriamente insuficiente en cuanto al régimen de excepciones y limitaciones al derecho de autor. En los párrafos siguientes nos referiremos a estos dos últimos temas y cómo su regulación a través de derecho interno ha resentido la conformación de un mercado interno.

133 Grijalva, Copyright \&, cit. nota n. 81, pp. 316 y 320 (sosteniendo el sinsentido del derecho de importación en un entorno en línea, en el cual los fronteras no existen y, en cambio, existe una verdadera "desterritorialización" jurídica).

134 Véase UNCTAD \& ICTSD, Resource, cit. nota n. 111, pp. 116-117.

135 Véase supra notas 123-127 y el texto que las acompaña.

136 Artículo 2 Decisión 351.

137 Artículos 12 y 17 Decisión 351.

138 Artículos 18 y 59 Decisión 351. 


\subsection{Regulación del dominio público}

Definir el dominio público puede constituir una tarea difícil, pero a efectos de este artículo diremos que el dominio público está constituido por todos aqueIlos contenidos no protegidos por los derechos de autor (i.e., sujetos al control exclusivo de una determinada persona). Por el contrario, potencialmente todos pueden beneficiarse del dominio público, pero nadie puede esgrimir derechos exclusivos sobre él ${ }^{139}$. Como se ha mencionado, el dominio público mejora el acceso a las obras al eliminar las autorizaciones y pagos por el uso establecidos usualmente en las leyes de derechos de autor ${ }^{140}$. El dominio público también permite a los creadores crear obras derivadas y proveer nuevos significados a los contenidos preexistentes. Además, el dominio público permite el desarrollo de iniciativas empresariales que suponen el uso de materiales disponibles en él. Entonces, el dominio público provee oportunidades a los usuarios, los creadores, y a toda suerte de intermediarios.

El dominio público está conformado básicamente por tres categorías de contenidos $^{141}$ : i) aquellos que no cualifican para la protección por los derechos de autor; ii) obras protegidas por los derechos de autor cuyo término de protección ha expirado, y iii) otras obras que ingresan al dominio público por varias peculiares razones que varían de un país a otro. De acuerdo a la Decisión, el primer grupo de contenidos incluye las meras ideas, el contenido técnico de obras científicas y su aprovechamiento comercial e industrial ${ }^{142}$. Este grupo también incluye aquellas creaciones que no satisfacen los requisitos para recibir protección por el derecho de autor, esencialmente porque carecen de originalidad o de fijación ${ }^{143}$. La originalidad y fijación de la obra son requeridos por el régimen común a efectos de que una obra merezca protección por el derecho de autor, ${ }^{144}$ pero la Decisión no precisa el significado de esos requisitos, sino que los deja a la determinación judicial.

139 Véase LiPsZYC, Copyright, cit. nota n. 15, p. 269.

140 Véase WIPO, Scoping, cit. nota n. 101, pp. 40-42 (refiriendo casos excepcionales en los cuales el uso de obras de dominio público requiere cierto pago).

141 Véase Id., pp. 23-37 (proveyendo una más extensa y detallada categorización de los contenidos disponibles en dominio público).

142 Artículo 5 Decisión 351.

${ }_{143}$ Artículos 3 y 4 Decisión 351. Véase Tribunal de Justicia de LA ComUnidad ANdina, Caso 10-IP-99, 11 de junio de 1999, Decisión final, pp. 3 (requiriendo originalidad en la "selección o disposición de las materias" a efectos de proteger por derechos autorales las bases de datos), y Caso 150-IP-2006, 12 de diciembre de 2006 (refiriéndose a la originalidad como un requisito para obtener protección por los derechos autorales sobre las compilaciones de obras).

144 En contra Antequera, Derecho, cit. nota n. 6, pp. 136-137 (sosteniendo que la Decisión 351 no establece la fijación como una exigencia general para obtener protección por el derecho de autor, sino que requiere ello excepcionalmente). 
Un segunda categoría de contenidos en dominio público está conformado por aquellos trabajos cuyo término de protección ha vencido. El régimen común de la Comunidad Andina adoptó la regla general de que la protección de los derechos de autor se extiende por la vida del autor más 50 años tras su muerte ${ }^{145}$. A pesar de la decepción expresada por algunos autores ${ }^{146}$, la Decisión fue respetuosa con el progreso hecho por algunos de los miembros de la Comunidad, los que habían extendido recientemente el plazo de protección en su legislación interna en cumplimiento con la Convención de Berna, la que también requiere protección por la vida del autor más 50 años tras su muerte ${ }^{147}$. La Decisión ayudó a estandarizar los plazos de protección, particularmente con respecto a aquellos países miembros de la Comunidad que todavía tenían términos más cortos de protección en su derecho interno ${ }^{148}$. Sin embargo, tal como el Convenio de Berna, la Decisión sólo establece un plazo mínimo y expresamente permite a los países miembros a proveer un plazo de protección más largo ${ }^{149}$.

El plazo de protección de los derechos de autor varía significativamente entre los países de la Comunidad Andina, lo cual crea otro obstáculo para el adecuado funcionamiento del mercado común. En términos generales, por ahora, Bolivia es el único país de la Comunidad con un plazo de protección igual a la vida del autor más 50 años post-mortem ${ }^{150}$. Ecuador y Perú han extendido el plazo a setenta años post-mortem ${ }^{151}$. Colombia es aún el país con el plazo de protección

\footnotetext{
145 Artículos 18-20 Decisión 351.

146 AnTEQuera, Derecho, cit. nota n. 6, pp. 921-922 (expresando su adhesión a que la armonización se hubiese producido en torno al plazo más largo previsto en la legislación colombiana, esto es, protección por la vida del autor más 80 años tras su muerte); Gómez Mucl, Gineli, "El Derecho de Autor y los Derechos Conexos en el Marco del Acuerdo sobre los Aspectos de los Derechos de Propiedad Intelectual relacionados con el Comercio, Acuerdo sobre los ADPIC", en ANTEQUerA, Ricardo; GómeZ Mucl, Gineli, Legislación sobre Derecho de Autor y Derechos Conexos, Ed. Jurídica Venezolana, Caracas, 1999, p. 121 (sugiriendo la adopción del plazo más extenso como plazo común de protección, a efectos de evitar una distorsión en el mercado común al concentrar la producción y distribución de obras en un determinado país).

147 Artículo 7 (1) Convenio de Berna.

148 Artículo 59 (1) Decisión 351 (extendiendo automáticamente los plazos de protección en curso en el derecho interno, si éstos eran más cortos que los previstos en la Decisión 351). Véase también, ANTEQUera, Derecho, cit. nota n. 6, p. 922 (mencionando el caso de ciertos plazos de protección más cortos previstos en la legislación peruana, los que fueron automáticamente extendidos con la adopción de la Decisión 351).

149 Artículos 18 y 59 (2) Decisión 351.

150 Artículos 18 y 19 Ley No 1322 de 1992: Ley de Derecho de Autor, Gaceta Oficial, 27 de abril de 1992 (Bolivia).

151 Artículos 80-81 Ley de Propiedad Intelectual, codificación 2006-013, Boletín Oficial, 19 de mayo de 1998 (Ecuador); artículos 52-56 Decreto Legislativo № 822: Ley sobre Derechos de Autor, Diario Oficial, 24 de abril de 1996 (Perú).
} 
más extenso, la vida del autor más ochenta años post-mortem ${ }^{152}$. Esto significa que un número importante de obras pueden estar disponibles en el dominio público en algunos países, pero aún en el dominio privado en otros, lo cual entraba el libre flujo de bienes y servicios desde un país a otro. Parece recomendable que la Comunidad Andina uniforme los plazos máximos de protección a efectos de remover el obstáculo antes mencionado. Esto, además, detendría cualquier extensión unilateral, especialmente si se tiene en mente la posibilidad de nuevos instrumentos internacionales que inciden en la materia ${ }^{153}$.

En adición a las diferencias en los plazos de protección entre los países miembros de la Comunidad, hay otros dos asuntos que han menoscabado la importancia del dominio público en los países de la Comunidad Andina: el reestablecimiento de los derechos en aquellas obras que fallaron en cumplir con su registro, y la adopción de plazos especiales de protección para obras de dominio público no publicadas previamente. El primer tema fue ya analizado ${ }^{154}$, el segundo se describe brevemente a continuación.

Las legislación interna de ciertos países provee un término especial de protección para las obras de dominio público que no han sido previamente publicadas, a efectos de estimular que ellas sean hechas de conocimiento público ${ }^{155}$. Este es el caso de Ecuador y Perú, cuyas legislaciones han otorgado derechos exclusivos por 25 y 10 años, respectivamente, no al autor de una obra sino a quien publica por primera vez una obra de dominio público que carecía de publicación ${ }^{156}$. Esta práctica afecta la credibilidad del dominio público al incrementar los costos transaccionales para determinar el estatus legal de una determinada obra. En este caso, esta regla no sólo incrementa tales costos en Ecuador y Perú, sino también en otros países en que la obra está en dominio público, pues la obra no podrá ser exportada a los primeros sin un análisis previo a efectos de establecer su estatuto legal, independientemente del país de origen de la obra ${ }^{157}$.

Una tercera categoría de obras es parte del dominio público por razones peculiares que varían significativamente de un país a otro. El dominio público

152 Artículos 11, 21-26, 28 Ley 23 de 1982 sobre derechos de autor, Diario Oficial, 19 de febrero 1982 (Colombia).

153 Véase artículo 4 (5) b) Trans-Pacific Partnership (en lo sucesivo TPP), Intellectual Property Rights Chapter, Draft - 10 de febrero de 2011 (proponiendo incrementar los plazos de protección de los derechos de autor más allá del estándar de 70 años para aquellas obras cuyo plazo de protección no se computa desde la muerte de una persona natural).

${ }^{154}$ Véase supra notas 94-98 y el texto que las acompaña.

155 Antequera; Ferreyros, El Nuevo, cit. nota n. 23, p. 427.

156 Artículo 104 Ley de Propiedad Intelectual, codificación 2006-013, Boletín Oficial, 19 de mayo de 1998 (Ecuador); artículo 145 Decreto Legislativo No 822: Ley sobre Derechos de Autor, Diario Oficial, 24 de abril de 1996 (Perú).

157 Véase Artículo 13 d) Decisión 351. 
es engrosado: en Ecuador, por las obras que son, a la vez, actos gubernamentales ${ }^{158}$; en Perú, por los actos gubernamentales y por el folclore ${ }^{159}$; en Bolivia y Colombia, por las obras del folclore y obras tradicionales de autores desconocidos, así como aquellas de autores que fallecen sin herederos o han renunciado a sus derechos ${ }^{160}$. Esta miscelánea lista de obras provee una oportunidad adicional para sumar obras al dominio público, pero su extremadamente singular composición hace difícil establecer con certidumbre el estatus jurídico de una obra, incrementando el costo transaccional para sus potenciales beneficiarios, lo cual traiciona el mismo propósito del dominio público.

Para que el mercado interno de la Comunidad Andina funcione apropiadamente, es necesario incrementar la convergencia no sólo respecto de la regulación del dominio privado, sino que también del dominio público. El régimen común en vigencia ha sido incapaz de proveer un claro entendimiento sobre qué obras integran el dominio público y el derecho interno de los países miembros de la Comunidad exhibe, además, significativas diferencias. Por ejemplo, existen diferencias en torno al uso comercial de las obras en dominio públi$\mathrm{CO}^{161}$, así como en cuanto a su relación con los derechos morales ${ }^{162}$. Además, sería apropiado introducir normas que limitasen la responsabilidad para casos de infracciones cometidas de buena fe, y medidas de observancia efectiva que eviten la apropiación indebida de las obras en dominio público, todas las cuales están completamente ausentes tanto en el régimen común como en la normativa interna de los países partes de la Comunidad Andina ${ }^{163}$.

\subsection{Excepciones y limitaciones a los derechos de autor}

El derecho de autor no garantiza derechos absolutos, sino que limitados. La ley establece limitaciones a través de las cuales se establece un cierto balance entre el simple interés privado del titular con el interés público de la sociedad

\footnotetext{
158 Artículo 10 Ley de Propiedad Intelectual, codificación 2006-013, Boletín Oficial, 19 de mayo de 1998 (Ecuador).

159 Artículos 9 y 57 Decreto Legislativo No 822: Ley sobre Derechos de Autor, Diario Oficial, 24 de abril de 1996 (Perú).

160 Artículos 58 y 59 Ley № 1322 de 1992: Ley de Derecho de Autor, Gaceta Oficial, 27 de abril de 1992 (Bolivia); artículos 187-189 Ley 23 de 1982 sobre derechos de autor, Diario Oficial, 19 de febrero 1982 (Colombia).

161 Véase artículos 60-62 Ley № 1322 de 1992: Ley de Derecho de Autor, Gaceta Oficial, 27 de abril de 1992 (Bolivia).

162 Véase artículos 10 y 82 Ley de Propiedad Intelectual, codificación 2006-013, Boletín Oficial, 19 de mayo de 1998 (Ecuador); y, artículo 29 Decreto Legislativo № 822: Ley sobre Derechos de Autor, Diario Oficial, 24 de abril de 1996 (Perú).

163 Véase WIPO, Scoping, cit. nota n. 101, pp. 67-73.
} 
para permitir a todos participar libremente de la vida cultura de la comunidad y disfrutar de los beneficios del progreso de las artes y las ciencias ${ }^{164}$. En este sentido, la protección de los derechos de autor es temporal, pues una vez el plazo de protección vence la obra pasa a conformar parte del dominio públi$\mathrm{CO}^{165}$; cualquiera puede beneficiarse de ella, pero nadie puede esgrimir derechos exclusivos en ella ${ }^{166}$. Sin embargo, contrariamente a lo que ha sido sugerido por algún autor ${ }^{167}$, el interés público no es sólo sobreviniente a la expiración del plazo de protección de los derechos de autor, dicho interés puede ser también coexistente con la protección. En este caso, la ley establece las denominadas excepciones o limitaciones al derecho de autor, permitiendo el uso de las obras sin autorización del ni pago al titular de los derechos. Las excepciones satisfacen diversos propósitos, tal como la concreción de obligaciones en materia de derechos humanos, la superación de defectos de mercado, y la consecución de otros intereses sociales ${ }^{168}$. Recientes análisis ponen también en evidencia la relevancia de un robusto sistema de excepciones y limitaciones al derecho de autor para favorecer la innovación y crecimiento económico ${ }^{169}$.

La Decisión 351 ha establecido una lista obligatoria de excepciones en el mercado interno ${ }^{170}$, pero también ha permitido la adopción de excepciones adicionales por el derecho interno de los países miembros de la Comunidad Andina, siempre que ellas cumplan con los requisitos establecidos en la denominada prueba de los tres pasos ${ }^{171}$. Como resultado de ello, en los países de la Comunidad coexisten dos regímenes de excepciones, las establecidas por el derecho comunitario y las previstas en el derecho interno de los países

\footnotetext{
164 Artículo 27 Declaración Universal de Derechos Humanos, adoptado por la Asamblea General de las Naciones Unidas en su Resolución Res. 217 (III) A, de 10 de diciembre de 1948.

165 Véase supra notas 145-152 y el texto que las acompaña.

166 Véase supra nota 139 y el texto que le acompaña.

167 SHerwood, Robert, Intellectual Property and Economic Development, Westview Press, 1990, p. 32 (sugiriendo que el interés público es meramente sobreviniente a la protección de la propiedad intelectual).

168 Véase LIPSZYC, Copyright, cit. nota n. 15, pp. 223-225; Carlos VILLALBA, "Duración de la Protección y Excepciones", en Anais do Seminário Internacional sobre Direitos Autorais, Editora da Universidade do Vale do Rio dos Sinos, São Leopoldo - Brasil, 1994, p. 168.

169 Véase Rogers, Thomas y SzamosszeGl, Andrew, Fair Use in the U.S. Economy: Economic Contribution of Industries Relying on Fair Use, CCIA, Washington D.C., 2011 (empleando la metodología de la Organización Mundial de la Propiedad Intelectual, ha establecido que la contribución de las actividades económicas que descansan en el fair use y sistemas de excepciones y limitaciones a los derechos de autor representan un sexto de la economía estadounidense y proveen uno de cada ocho puestos de trabajo en ella).

170 Artículo 22 Decisión 351.

171 Artículo 21 Decisión 351. Véase también, artículo 9 (2) Convenio de Berna; y artículo 13 Acuerdo sobre los ADPIC.
} 
miembros ${ }^{172}$. Curiosamente, en dos situaciones que han suscitado creciente interés público -el caso de las personas con discapacidades y el caso de las bibliotecas- no fueron reconocidas excepciones en el régimen común, dejando la situación para ser resuelta por el derecho interno de los países ${ }^{173}$. Naturalmente, tales omisiones en el régimen común y las diferencias de las legislaciones nacionales han creado algunos inconvenientes y severas asimetrías dentro de la Comunidad Andina ${ }^{174}$.

El acceso a obras protegidas por los derechos de autor es particularmente complicado para las personas con discapacidades, razón por la cual es usual en el derecho comparado constatar la adopción de excepciones a favor de ellas y de las instituciones que les proveen acceso a las obras ${ }^{175}$. Desafortunadamente, la Decisión no estableció una excepción específica a favor de ellas, ni tampoco lo hace la legislación interna de Bolivia, Colombia, o Ecuador ${ }^{176}$. En cambio, Perú sí ha adoptado una excepción, aun cuando bastante limitada, exceptuando de autorización del y pago al titular por la reproducción sin ánimo de lucro de obras a favor de personas ciegas en Braille u otros procesos específicos ${ }^{177}$. Sin embargo, las complejidades y el alto costo de proveer acceso a personas con discapacidades, así como la urgencia de permitir algunas economías de escala para tal propósito, requiere una solución en el régimen común en vez de que en el derecho interno de los países miembros de la Comunidad. La propuesta de tratado para resolver el problema de acceso a personas con discapacitados actualmente analizada en la Organización Mundial de la Propiedad Intelectual (OMPI) puede ser un excelente punto de partida para la Comunidad Andi$\mathrm{na}^{178}$.

\footnotetext{
172 Antequera, Copyright, cit. nota n. 9, pp. 92-93.

173 Artículo 21 Decisión 351.

174 Véase AnTEQuera, Derecho, cit. nota n. 6, pp. 922-923 (mencionando que una completa armonización de las excepciones en la Comunidad Andina fue obstaculizado por las diferencias entre sus países miembros en cuanto a la extensión de los derechos exclusivos).

175 Véase World Intellectual Property Organization - Standing Committee on Copyright and Related Rights, Study on Copyright Limitations and Exceptions for the Visually Impaired (preparado por Judith Sullivan), SCCR/15/7, 20 de febrero de 2007.

176 Véase Rodríguez Moreno, Sofía, Era Digital y las Excepciones y Limitaciones al Derecho de Autor, Universidad Externado de Colombia, 2004, pp. 266-268 (sustentando la necesidad de disponer de una excepción a favor de las personas con discapacidades en la legislación colombiana).

177 Artículo 43 g) Decreto Legislativo № 822: Ley sobre Derechos de Autor, Diario Oficial, 24 de abril de 1996 (Perú), modificado por la Ley № 27.861 que exceptúa el pago de derechos de autor por la reproducción de obras para invidentes.

178 Propuesta del Brasil, el Ecuador y el Paraguay en relación la limitaciones y excepciones: Propuesta de tratado de la Unión Mundial de Ciegos (UMC), Documento OMPI, SCCR/18/5, 25 de mayo de 2009. En: http://www.wipo.int/edocs/mdocs/copyright/es/sccr_18/sccr_18_5.doc [visitado el 13/06/2011].
} 
Una segunda situación que requiere solución a nivel de la Comunidad Andina y no sólo de derecho interno es el préstamo público de obras por bibliotecas. La Decisión 351 reconoce limitadas excepciones para las bibliotecas ${ }^{179}$, pero ellas no cubren el préstamo bibliotecario ${ }^{180}$, el cual podría ser provisto por el derecho interno. Como resultado de esto, Colombia ha adoptado la posición de que los derechos exclusivos del titular incluyen el derecho de préstamo público de las obras, sin excepción alguna a favor de las bibliotecas ${ }^{181}$. Ecuador parece seguir similar posición ${ }^{182}$. Bolivia, en cambio, no ha otorgado derechos exclusivos en el préstamo público y, consiguientemente, las bibliotecas no padecen estas restricciones del derecho de autor ${ }^{183}$. Perú ha conferido derechos exclusivos en el préstamo ${ }^{184}$, pero, al mismo tiempo, también ha previsto una excepción específica para el préstamo público por bibliotecas ${ }^{185}$.

Al igual que en el caso del dominio público, la Comunidad Andina no ha convergido suficiente con respecto a las excepciones y limitaciones a los derechos de autor. La Comunidad Andina está en deuda con bibliotecas y museos, con instituciones educacionales, con las personas con discapacidades, con editores, y con desarrolladores de software, entre otros. Esta deuda no sólo menoscaba el adecuado funcionamiento del mercado interno, sino que también compromete los derechos humanos, la inclusión social, la innovación y otros fines de interés público.

\section{El régimen común requiere una urgente actualización de sus disposiciones}

Adoptada en 1993, la Decisión 351 recogió en sus disposiciones la mayor parte de las discusiones atingentes a la interacción entre las nuevas tecnologías y los derechos de autor en aquellos años. Así resolvió temas esenciales, tales

179 Artículo 22 c) Decisión 351 (permitiendo la reproducción individual de obras para efectos de su preservación y sustitución por bibliotecas y archivos sin fines de lucro).

180 Antequera, Copyright, cit. nota n. 9, pp. 86-87 (consignando que el préstamo público no estuvo siquiera en la mesa de negociaciones de la Comunidad Andina).

181 Véase supra notas 57-58 y el texto que las acompaña.

182 Artículos 19, 23, 83 y 84 Ley de Propiedad Intelectual, codificación 2006-013, Boletín Oficial, 19 de mayo de 1998 (Ecuador) (reconociendo una comprensiva extensión a los derechos exclusivos de autor, sin excepción respecto del préstamo bibliotecario de obras).

183 Artículo 15 Ley No 1322 de 1992: Ley de Derecho de Autor, Gaceta Oficial, 27 de abril de 1992 (Bolivia).

${ }_{184}$ Artículo 34 Decreto Legislativo No 822: Ley sobre Derechos de Autor, Diario Oficial, 24 de abril de 1996 (Perú).

185 Artículo 43 (f) Decreto Legislativo № 822: Ley sobre Derechos de Autor, Diario Oficial, 24 de abril de 1996 (Perú). 
como la protección del software y las bases de datos ${ }^{186}$, así como el efecto de la puesta a disposición pública en línea ${ }^{187}$. Hasta cierto punto, es justo aseverar que la Decisión cristalizó el estado del arte existente a comienzos de los años noventa. Sin embargo, la Decisión no anticipó varios temas y rápidamente quedó desfasada. De entre tales temas, los más significativos son la regulación de las medidas tecnológicas de protección y el régimen de responsabilidad que tiene lugar en caso de infracción a los derechos de autor en línea.

La adecuación de la normativa sobre derechos de autor a los desafíos de las nuevas tecnologías ha corrido, entonces, esencialmente de cargo del derecho interno de los países miembros de la Comunidad Andina. En la práctica, cada país ha adoptado leyes de adecuación en la medida requerida por los compromisos internacionales de que es parte ${ }^{188}$. Los Tratados Internet de la OMPI ${ }^{189}$ y los tratados bilaterales de libre comercio, especialmente aquellos suscritos con los Estados Unidos, han sido los principales motores de dicha actualización. Como resultado de ello, los países miembros de la Comunidad Andina disponen de un régimen de protección a los derechos de autor en el entorno en línea bastante idiosincrático, con diferencias significativas de un país a otro. Dichas diferencias deberían ser minimizadas en el evento de adoptarse un nuevo régimen común que responda más apropiadamente a los desafíos de las nuevas tecnologías. En las páginas siguientes analizaremos algunos de ellos a la luz de su inclusión en la negociación de tratados de libre comercio.

\section{El régimen común ha sido incapaz de proveer una plataforma} común para las negociaciones con terceros países: efectos de los tratados de libre comercio

De cara a las negociaciones de acuerdos bilaterales con terceros países en los cuales se ha incluido el tratamiento de temáticas relativas a la propiedad intelectual, era previsible que la Comunidad Andina trabajase en una agenda común y condujese sus negociaciones en bloque. Sin embargo, en 2004, la Decisión 598 permitió a los países de la Comunidad Andina negociar con terceros países, priorizando las negociaciones comunitarias o conjuntas cuando ellas fuesen posible, pero también permitiendo las negociaciones individuales

\footnotetext{
186 Artículo 4 Decisión 351.

187 Artículos 13 b) y 15 Decisión 351.

188 Véase Anexo: Tabla 1: Comunidad Andina de Naciones, acuerdos internacionales sobre derechos de autor en que sus miembros son partes.

189 Tratado de la OMPI sobre Derecho de Autor, adoptado en Ginebra el 20 de diciembre de 1996; y, Tratado de la OMPI sobre Interpretación o Ejecución y Fonogramas, adoptado en Ginebra el 20 de diciembre de 1996.
} 
en casos excepcionales ${ }^{190}$. De acuerdo a la Decisión 598, en este último caso los países negociadores deben informar a la Comunidad Andina sobre sus negociaciones individuales y preservar el régimen común ${ }^{191}$, pero ni la Comunidad ni ninguno de los países miembros tiene por regla general el derecho a objetar tales negociaciones o acuerdos ${ }^{192}$.

La Decisión 598 ha facilitado el movimiento desde el multilateralismo hacia el bilateralismo dentro de la Comunidad Andina, cuyos miembros han intensificado sus negociaciones con terceros países ${ }^{193}$. En los siguientes años a la adopción de la mencionada Decisión, Colombia ha suscrito acuerdos comerciales con Canadá, Chile, la Unión Europea, y los Estados Unidos ${ }^{194}$; Perú con los mismos países más China, México, Singapur, y Tailandia ${ }^{195}$; Ecuador tan sólo con Chile ${ }^{196}$; y Bolivia con ninguno ${ }^{197}$. Todos dichos acuerdos son comprensivos, incluyendo varias disciplinas; varios de ellos incluyen compromisos en materia de propiedad intelectual, aunque generalmente refiriendo a estándares internacionales relativamente bien asentados $^{198}$. Sin embargo, de todos aquellos acuerdos bilaterales firmados por

190 Artículo 1 Decisión 598 Relaciones comerciales con terceros países, adoptada por la Comisión del Acuerdo de Cartagena, 11 de julio de 2004, Gaceta Oficial de la Comunidad Andina, N ${ }^{\circ}$ 1092, 6 de julio de 2004.

191 Artículo 2 Decisión 598.

192 Artículo 4 Decisión 598.

193 Véase Organization of American States, Foreign Trade Information System. En: http://www.sice.oas. org/agreements_e.asp 2004 [visitado el 31/05/2011].

194 Véase Organization of American States, Foreign Trade Information System, Information on Colombia. En: http://www.sice.oas.org/ctyindex/COL/COLagreements_e.asp [visitado el 31/05/2011].

195 Véase Organization of American States, Foreign Trade Information System, Information on Peru. En: http://www.sice.oas.org/ctyindex/PER/PERagreements_s.asp [visitado el 31/05/2011].

196 Véase Organization of American States, Foreign Trade Information System, Information on Ecuador. En: http://www.sice.oas.org/ctyindex/ECU/ECUagreements_e.asp [visitado el 31/05/2011].

197 Véase Organization of American States, Foreign Trade Information System, Information on Bolivia. En: http://www.sice.oas.org/ctyindex/BOL/BOLagreements_e.asp [visitado el 31/05/2011].

198 E.g., de los ocho acuerdos de libre comercio suscritos por Perú tras la adopción de la Decisión 598: cuatro no incluyen disposiciones en materia de propiedad intelectual (aquéllos firmados con Canadá, Chile, Singapur, y Tailandia), dos incluyen algunas disposiciones en la materia, pero no sobre derechos de autor (aquéllos firmados con China y México). En consecuencia, sólo dos de los ocho tratados de libre comercio suscritos por Perú incluyen disposiciones concernientes a derecho de autor, aquéllos suscritos con la Unión Europea y con los Estados Unidos. El primero básicamente requiere a las partes cumplir con preexistentes instrumentos internacionales en materia de derechos de autor, mientras que el segundo establece compromisos que van más allá de lo previsto en dichos instrumentos internacionales. Véase supra notas 204-209 y el texto que las acompaña. Véase también, Roffe, Pedro; SANTA Cruz, Maximiliano, Los derechos de propiedad intelectual en los acuerdos de libre comercio celebrados por países de América Latina con países desarrollados, Serie Comercio Internacional, Comisión Económica para América Latina y el Caribe, CEPAL, 2006. 
países miembros de la Comunidad Andina, los tratados de libre comercio suscritos por Estados Unidos con Perú y con Colombia son indudablemente los más relevantes a efectos de comprender el reciente desarrollo del derecho interno de tales países de la Comunidad ${ }^{199}$.

A pesar de que las negociaciones de los tratados de libre comercio con los Estados Unidos comenzaron revistiendo carácter comunitario ${ }^{200}$, en 2006, dichos acuerdos fueron concluidos sólo en los casos de Colombia y Perú ${ }^{201}$. Ni Ecuador ni Bolivia son partes de similares acuerdos; mientras que Venezuela no sólo no es parte, sino que, además, denunció el Tratado de la Comunidad Andina precisamente por la conclusión de acuerdos por Colombia y Perú con los Estados Unidos ${ }^{202}$. De dichos acuerdos, sólo el peruano está en vigor, mientras que el colombiano no ha sido aún aprobado por el Congreso de los Estados Unidos, el cual ha esgrimido reparos respecto del respeto y observancia de los derechos humanos y laborales en Colombia ${ }^{203}$.

A través de sus respectivos tratados de libre comercio, Colombia y Perú asumieron diversos compromisos que incrementan la protección y observancia de las leyes sobre propiedad intelectual de acuerdo con el derecho interno estadounidense, pero más allá de los estándares acordados en foros internacionales ${ }^{204}$. En materia de derechos de autor, sin afán de ser exhaustivos, las partes de dichos tratados de libre comercio se han obligado a proveer un plazo de protección igual a la vida del autor más 70 años post mortem auctori ${ }^{205}$, otorgar protección a las medidas de protección tecnológicas y la información de gestión de derechos más allá de lo previsto en los Tratados

\footnotetext{
199 Acuerdo de Promoción Comercial Colombia - Estados Unidos, suscrito el 22 de noviembre de 2006, y Acuerdo de Promoción Comercial Perú - Estados Unidos, suscrito el 12 de abril de 2006.

${ }^{200}$ Véase Taccone, Juan José y Nogueira, Uziel (eds.), Andean Report 2002-2004, Institute for the Integration of Latin America and the Caribbean (INTAL), IDB-INTAL, Buenos Aires, 2005, pp. 38-40.

201 Roffe; Santa Cruz, Los derechos, cit. nota n. 197, p. 44.

202 Carta de Alí Rodríguez Araque, Ministro de Relaciones Exteriores de Venezuela a la Presidenta y demás Miembros de la Comisión de la Comunidad Andina (22 de abril de 2006) (denunciando el Acuerdo de Cartagena y retirándose de la Comunidad Andina).

${ }^{203}$ Carta de Charles B. Rangel, Chairman of the Committee on Ways and Means, y Sander M. Levi, Chairman of the Subcommittee on Trade, ambos de la Cámara de Representantes del Congreso de los Estados Unidos a Susan C. Schwab, Representante de Comercio de los Estados Unidos (10 de mayo 2007).

204 Roffe; Santa Cruz, Los derechos, cit. nota n. 197, pp. 10, 38, 41-43.

205 Artículo 16.6.7 TLC Colombia-Estados Unidos, y artículo 16.6.7. TLC Perú-Estados Unidos.
} 
Internet de la OMP2 ${ }^{206}$, regularizar el uso de software por los gobiernos, ${ }^{207}$ ampliar las facultades de las autoridades aduaneras y de persecución penal a efectos de obtener el cumplimiento de las leyes sobre propiedad intelectual $^{208}$; y adoptar medidas especiales para garantizar la observancia de las leyes sobre derechos de autor en Internet ${ }^{209}$. Este artículo describe los efectos de dichos acuerdos en el derecho interno de los países miembros de la Comunidad Andina en dos aspectos relevantes: la regulación de las medidas de protección tecnológica y el régimen de responsabilidad de los prestadores de servicios en línea.

\subsection{Medidas de protección tecnológica}

Las medidas de protección tecnológica, también conocidas como medidas tecnológicas efectivas, son dispositivos técnicos empleados por los titulares de derechos autorales en relación con el ejercicio de sus derechos exclusivos, restringiendo actos no autorizados. Entre ellos, pueden mencionarse los sistemas de regionalización de los DVD, los sistemas de protección anti-copiado de los programas computacionales, y las limitaciones en los archivos $\mathrm{PDF}^{210}$. $\mathrm{Ni}$ la Decisión ni el Acuerdo sobre los ADPIC incluyen disposiciones especiales sobre medidas de protección tecnológica ${ }^{211}$. Mediante los Tratados Internet de la OMPI los países partes se obligan a proporcionar "protección jurídica adecuada y recursos jurídicos efectivos contra la acción de eludir" las mencionadas medidas ${ }^{212}$. A excepción de Bolivia, los países de la Comunidad Andina son partes de ambos Tratados Internet de la $\mathrm{OMPl}^{213}$, y han implementado sus disposiciones en el derecho interno mediante disposiciones criminales en con-

\footnotetext{
${ }^{206}$ Véase artículos 16.7.4 y 16.7.5 TLC Colombia-Estados Unidos; y, artículos 16.7.4 y 16.7.5 TLC Perú-Estados Unidos. Véase en cambio, artículos 11 y 12 Tratado de la OMPI sobre Derecho de Autor; 18 y 19 Tratado de la OMPI sobre Interpretación o Ejecución y Fonogramas.

207 Artículo 16.7.6 TLC Colombia-Estados Unidos; y, artículo 16.7.6 TLC Perú-Estados Unidos.

208 Artículos 16.11.23 y 16.11.27 d) TLC Colombia-Estados Unidos; y, artículos 16.11.23 y 16.11.27

d) TLC Perú-Estados Unidos.

209 Artículo 16.11.29 TLC Colombia-Estados Unidos, y artículo 16.11.29 TLC Perú-Estados Unidos.

210 Artículo 11 Tratado de la OMPI sobre Derecho de Autor; 18 Tratado de la OMPI sobre Interpretación o Ejecución y Fonogramas.

211 Roffe; Santa Cruz, Los derechos, cit. nota n. 197, p. 42.

212 Artículo 11 Tratado de la OMPI sobre Derecho de Autor; 18 Tratado de la OMPI sobre Interpretación o Ejecución y Fonogramas.

${ }^{213}$ Véase Anexo: Tabla 1: Comunidad Andina de Naciones, acuerdos internacionales sobre derechos de autor en que sus miembros son partes.
} 
tra de la elusión de las medidas de protección tecnológica, las cuales difieren significativamente de un país a otro ${ }^{214}$.

Los tratados de libre comercio también incluyen disposiciones relativas a las medidas de protección tecnológica ${ }^{215}$, las cuales van más allá de los estándares de los Tratados Internet de la OMPI y siguen, en cambio, la normativa estadounidense $^{216}$, establecida en la altamente controvertida Digital Millennium Copyright $\mathrm{Act}^{217}$. En los tratados de libre comercio, las partes son requeridas a adoptar no sólo "protección jurídica adecuada" sino también "sanciones criminales"218. Adicionalmente, estas sanciones deben aplicarse no sólo a la elusión de las medidas de protección tecnológica (normas anti-elusión), sino que también a la comercialización de mecanismos que permiten a los usuarios su elusión (normas anti-comercialización) ${ }^{219}$. A la fecha, solamente Perú ha adoptado una ley implementando dichos compromisos ${ }^{220}$.

Como resultado de la singular implementación de los compromisos internacionales de los países miembros de la Comunidad Andina, la normativa vigente sobre medidas de protección tecnológica en los países miembros es completamente diferente de un país a otro. Tal diferenciación podrían incrementarse gracias al Trans-Pacific Partnership Agreement, en cuya negociación Perú está involucrado, ya que, de acuerdo a la propuesta estadounidense, se establecerían sanciones criminales para las infracciones a las normas anti-elusión y para las

\footnotetext{
${ }^{214}$ Artículo 272 números 1 y 3 Código Penal (Colombia) (imponiendo sanciones criminales tanto para la elusión de medidas de protección tecnológica como para la comercialización de mecanismos que permiten tal elusión, sin excepciones). En Ecuador, véase artículos 25 y 325 Ley de Propiedad Intelectual, codificación 2006-013, Boletín Oficial, 19 de mayo de 1998 (Ecuador) (la primera disposición otorga a los titulares de derecho el derecho de adoptar medidas de protección tecnológicas y asimila la comercialización de dispositivos que permiten su elusión a una violación de los derechos autorales, sin excepciones; la segunda disposición adoptando sanciones criminales contra la comercialización de mecanismos que permiten la elusión de la medidas de protección tecnológica, sin excepción). En Perú, véase artículo 187 Decreto Legislativo № 822: Ley sobre Derechos de Autor, Diario Oficial, 24 de abril de 1996 (Perú) y artículo 218 Código Penal (adoptando sanciones criminales contra la comercialización de mecanismos que permiten la elusión de las medidas de protección tecnológica, sin excepción alguna).

215 Artículo 16.7.4 TLC Colombia-Estados Unidos; y, artículo 16.7.4. TLC Perú-Estados Unidos.

21617 U.S.C. $\S \S 1201$ - 1205 (2006).

217 Digital Millennium Copyright Act, Pub. L. № 105-304, 112 Stat. 2860, codificada en la sección 17 de la U.S.C. Véase también Roffe; SANTA Cruz, Los derechos, cit. nota n. 197, pp. 54-56; y EleCtronic Frontier Foundation, "Unintended Consequences: Twelve Years under the DMCA". En: http://www.eff. org/wp/unintended-consequences-under-dmca [visitado el 20/07/2011].

218 Artículo 16.7.4 a) TLC Colombia-Estados Unidos; y, artículo 16.7.4 a) TLC Perú-Estados Unidos.

219 Artículo 16.7.4 a) (ii) TLC Colombia-Estados Unidos; y, artículo 16.7.4 a) (ii) TLC Perú-Estados Unidos.

220 Artículo 187 Decreto Legislativo No 822: Ley sobre Derechos de Autor, Diario Oficial, 24 de abril de 1996 (Perú); y artículo 218 Código Penal (Perú).
} 
normas anti-comercialización, incluso si no existe infracción a los derechos autorales ${ }^{221}$. Entretanto, la situación actual ya afecta la competencia dentro de la Comunidad Andina, especialmente en el sector tecnológico, y menoscaba los derechos de los consumidores. Podría sugerirse que la Comunidad Andina necesita extender el régimen común a las medidas de protección tecnológica, a efectos de preservar el apropiado funcionamiento del mercado interno y, a la vez, obtener una política común ante terceros países, para el caso de futuras negociaciones en la materia.

\subsection{Responsabilidad de los prestadores de servicio en línea}

A diferencia de cualquier otro instrumento internacional en material de propiedad intelectual, los tratados de libre comercio suscritos por Perú y Colombia con los Estados Unidos incluyen disposiciones relativas a la observancia de los derechos de autor en el entorno en línea ${ }^{222}$. Siguiendo la senda de la normativa estadounidense ${ }^{223}$, dichos tratados incluyen un detallado régimen legal que reglamenta la responsabilidad de los prestadores de servicio en línea por la infracción a los derechos de autor que tienen lugar en Internet, incluyendo un sistema de notificación de infracciones, de bajada de contenidos infractores y de identificación de supuestos infractores, entre otros ${ }^{224}$. En términos generales, estas disposiciones proveen un "puerto seguro" a los prestadores de servicio en línea que contribuyen a la protección de los derechos autorales ${ }^{225}$. Algunos académicos han sostenido que dichas disposiciones hacen de los prestadores de servicio los "policías" de Internet ${ }^{226}$.

Actualmente, dentro de la Comunidad Andina existen diferentes aproximaciones a cómo regular la responsabilidad de los prestadores de servicios en línea. Bolivia no tiene compromisos ni regulación en la materia. Colombia ha asumido compromisos en el tratado de libre comercio y, pese a que éste no ha entrado en vigencia aún, ha introducido un controvertido proyecto de ley

\footnotetext{
221 Artículo 4.9 c) TPP, cit. nota n. 153.

222 Artículo 16.11.29 TLC Colombia-Estados Unidos; y, artículo 16.11.29 TLC Perú-Estados Unidos.

223 Véase 17 U.S.C. § 512 (2006).

224 Artículo 16.11.29 TLC Colombia-Estados Unidos; y, artículo 16.11.29 TLC Perú-Estados Unidos.

225 Denominado "puerto seguro" porque aquellos prestadores de servicios en línea que adoptan las medidas técnicas, organizacionales, y legales requeridas por la ley quedan inmunizados de responsabilidad por la infracción de los derechos de autor cometidas por sus usuarios.

${ }^{226}$ Véase, e.g., XUE, Hong Enforcement for Development: Why not an Agenda for the Developing World?, in Xuan Lı and Carlos CorreA (Ed.), Intellectual Property Enforcement: International Perspective, Edward Elgar Publishing Limited, 2009, pp. 144-145.
} 
a tramitación legislativa ${ }^{227}$. Perú está retrasado en la implementación de los compromisos asumidos en el tratado de libre comercio al respecto ${ }^{228}$. Ecuador ha adoptado motu proprio una regulación, la cual es más general y draconiana aún que el modelo contemplado en los tratados de libre comercio ${ }^{229}$. Este panorama podría diversificarse aún más si las negociaciones del TPP progresan sobre la base de la propuesta estadounidense, la cual extiende el ámbito de aplicación del régimen de responsabilidad de los prestadores de servicio en línea a la protección de las marcas comerciales ${ }^{230}$.

Las significativas diferencias entre las regulaciones de los países miembros de la Comunidad Andina respecto de la responsabilidad de los prestadores de servicio por las infracciones a los derechos de autor pueden suscitar un inapropiado funcionamiento del mercado interno ${ }^{231}$. Los costos operacionales de algunos prestadores de servicios en línea son mayores en unos países que en otros sólo por su diferente régimen legal. En algunos casos, ello puede distraer comercio al transferir la prestación de servicios hacia países con menores costos; este podría ser el caso, por ejemplo, de servicios de almacenamiento de contenidos. En cambio, los prestadores de servicio de acceso se ven forzados a tolerar el asimétrico funcionamiento del mercado interno, por sus aún fuertes vínculos con infraestructuras físicas, tales como proveedores de telefonía y cable.

227 Apesar de que el TLC Colombia-Estados Unidos no está aún en fuerza debido a la falta de aprobación por el Congreso de los Estados Unidos, el gobierno colombiano ha introducido a debate legislativo un proyecto de ley que implementa un régimen de responsabilidad para los prestadores de servicio en línea. La iniciativa, que debería ser discutida durante el presente período legislativo, establecería una regulación que aplicaría no sólo a compañías sino a toda persona que provee algún servicio en línea, obligándoles a bajar contenidos e identificar usuarios sin orden judicial, y autoriza la desconexión de supuestos infractores mediante decisión judicial adoptada in limini litis. Véase MINISTERIO DEL INTERIOR Y DE JUSTICIA DE COLOMBIA, Proyecto de Ley por el cual se regula la responsabilidad por las infracciones al derecho de autor y los derechos conexos en Internet, en: http:/www.senado.gov.co/az-legislativo/ proyectos-de-ley?download=420\%3Aderechos-de-autor-en-internet [visitado el 20/07/2011].

228 Anexo 16.1 TLC Perú-Estados Unidos (fijando un plazo de un año desde su entrada en fuerza, que tuvo lugar el 1 de febrero de 2009, para la implementación de las disposiciones sobre responsabilidad de los prestadores de servicios en línea).

229 Artículo 292 Ley de Propiedad Intelectual, codificación 2006-013, Boletín Oficial, 19 de mayo de 1998 (Ecuador) (estableciendo responsabilidad solidaria en el operador o cualquier otra persona natural o jurídica que tenga el control de un sistema informático interconectado a una red de comunicaciones digitales a través de la cual se comete infracción de los derechos de propiedad intelectual, cuando ha tenido razonable conocimiento de la infracción, incluyendo cuando el titular de los derechos ha notificado a tal persona).

230 Artículo 16 TPP, cit. nota n. 153.

${ }^{231}$ Véase Julì-BArceló, Rosa, "On-line Intermediary Liability Issues: Comparing E.U. and U.S. Legal Frameworks", European Intellectual Property Review Vol. 22, № 3, 2000, p. 116 (criticando los negativos efectos en el funcionamiento del mercado común de la Unión Europea a raíz de diferencias en la legislación interna de cada uno de sus Estados miembros). 
La adopción de un adecuado régimen de responsabilidad para los prestadores de servicio en línea para el caso de infracciones a los derechos de autor es una tarea extremadamente compleja, que requiere un delicado balance entre los intereses en conflicto: titulares de derechos buscando protección para su propiedad intelectual; usuarios preocupados por sus derechos fundamentales y derechos como consumidores; y prestadores de servicios en línea a la espera de disponer de un componente esencial para su modelo de negocios, el marco regulatorio. A medida que la economía digital progresa hacia más complejos servicios proveídos a través de Internet -tales como telefonía IP, video bajo demanda, cloud computing, y conferencias en línea- la regulación de la responsabilidad de los prestadores por infracción a la propiedad intelectual se transforma en un elemento crítico. Aquí, un marco normativo que varía de un país a otro es ineficiente, porque crea costos técnicos, organizacionales y transaccionales; a medida que la economía digital deviene en global, ella requiere armonización internacional, o al menos regional, lo que, desafortunadamente, el régimen común no provee a los países miembros de la Comunidad Andina.

\section{INCREMENTANDO LA CONVERGENCIA NORMATIVA EN DERECHOS DE AUTOR DENTRO DE LA COMUNIDAD ANDINA}

Como fue mencionado precedentemente, la Decisión 351 fue concebida como un primer paso en el proceso de convergencia dentro de la Comunidad Andina en torno a la regulación de los derechos de autor y conexos; un esfuerzo preclaro y ambicioso que contribuyó efectivamente a cierta armonización a comienzos de los años noventa ${ }^{232}$. Sin embargo, los efectos de aquel primer paso se han diluido con los años, a raíz de la emergencia de nuevos tópicos, tecnologías y compromisos internacionales. La falta de convergencia en derechos de autor entre los países miembros de la Comunidad Andina puede transformarse en un serio obstáculo para la integración regional, especialmente en el contexto de la economía de la información, al obstruir el libre flujo de bienes y servicios y, a la vez, crear ventajas competitivas artificiales de un país a otro basadas en simple diferencias en su régimen legal.

En los próximos años, la Comunidad Andina debería incrementar sus esfuerzos por converger en una actualización de su régimen común en materia de derechos de autor y conexos. Esto permitiría a los países de la Comunidad armonizar su derecho interno, avanzar su propia agenda antes que la de terceros países, y superar los obstáculos para la futura integración económica de la región, entre otros objetivos de política pública. En este contexto, a lo menos cuatro asuntos deberían ser incluidos en una nueva Decisión, estos son: la ex-

${ }^{232}$ Véase supra notas 6, 25, y 37, así como el texto que las acompaña. 
tensión de los derechos autorales, limitaciones y excepciones, dominio público y observancia de los derechos de autor.

La Decisión 351 hace explícita la falta de acuerdo en la Comunidad Andina en torno a la extensión de los derechos de autor, al permitir que tanto derechos morales como económicos sean incrementados por el derecho interno de sus países miembros ${ }^{233}$. Como resultado de ello, se han suscitado importantes diferencias entre los países, desde el limitado reconocimiento de derechos de Bolivia a la omnicomprensiva protección de Colombia ${ }^{234}$. En el siguiente paso hacia una convergencia normativa en materia de derechos autorales, los países deberían fijar la extensión de derechos que se acuerda a los titulares, particularmente respecto del préstamo público sin fines de lucro y el derecho de exportación al mercado interno, el que se relaciona con el agotamiento de los derechos. Es recomendable ajustar la extensión de los derechos a una lista cerrada y adoptar, cuando menos, un agotamiento regional de los derechos.

Las limitaciones y excepciones a los derechos de autor también requieren su armonización en la Comunidad Andina. Este artículo ya ha mencionado la necesidad de al menos tres excepciones específicas: para el desarrollo de software, para el adecuado funcionamiento de bibliotecas y para permitir el acceso a las obras por personas con discapacidad. Esta no es una lista exhaustiva, pues otras varias excepciones requieren ser reconocidas en el régimen común, a través de las cuales se facilita el acceso al conocimiento por la población y, al mismo tiempo, se crean oportunidades para la innovación y negocios en los países. Algunas de dichas excepciones son estándar común, inclusive entre países desarrollados, tales como aquellas relativas a educación en línea, obras huérfanas y funcionamiento de Internet ${ }^{235}$. Otras flexibilidades son permitidas por el derecho internacional a los países en desarrollo, como el sistema de licencias obligatorias para la traducción y/o reproducción de obras en idiomas extranjeros $^{236}$. Ninguna de las recién mencionadas ha sido adoptada por la Decisión 351, pero algunas por el derecho interno de los países miembros ${ }^{237}$,

\footnotetext{
233 Véase supra notas 53-60 y el texto que las acompaña.

${ }^{234}$ Véase supra notas 58-59 y el texto que las acompaña.

235 Véase World Intellectual Property Organization, Database on Studies and Presentations on Limitations and Exceptions. En: http://www.wipo.int/copyright/en/limitations/studies.html [visitado el 20/07/2011].

${ }^{236}$ Anexo del Convenio de Berna: Disposiciones especiales relativas a países en desarrollo (autorizando a los países en desarrollo para conceder licencias obligatorias no exclusivas y no transferibles para la traducción y/o reproducción de obras publicadas impresas o en análogas formas de reproducción a efectos de satisfacer necesidades de los países asociadas a la educación e investigación, con pago de compensación para el titular de los derechos de autor respectivos).

${ }^{237}$ Véase, e.g., artículos 41 (c) y 43 (f) Decreto Legislativo № 822: Ley sobre Derechos de Autor, Diario Oficial, 24 de abril de 1996 (Perú) (estableciendo limitadas excepciones que permite la comunicación
} 
a pesar del hecho de que la ausencia de ellas en el régimen común podrían afectar el adecuado funcionamiento del mercado interno y la competitividad de los países de la Comunidad en el mercado global.

El régimen común contribuyó a armonizar los plazos de protección del derecho de autor al empujar a los países a cumplir con el estándar mínimo de protección previsto internacionalmente. Sin embargo, el régimen común falló al no contener la verdadera carrera por incrementar los plazos de protección en el derecho interno de los países miembros de la Comunidad, lo cual ha redundado en la creación de barreras artificiales para el libre flujo de obras dentro del mercado interno ${ }^{238}$. Esto se ha agravado por el reconocimiento por derecho interno de obras en dominio público por razones distintas a la expiración de sus plazos de protección ${ }^{239}$. En dominio público, el régimen común tiene varios asuntos sin resolver y que deberían ser abordados en una actualización de la Decisión. Ésta debería adoptar plazos de protección y normas de cómputo uniformes, converger en la composición del dominio público para casos distintos a la extinción del plazo de protección, armonizar las reglas sobre uso comercial, derechos morales y observancia del dominio público. Es altamente recomendable también la introducción de flexibilidades para casos de infracciones de buena fe fundadas en la convicción da hacer uso de obras en dominio público, particularmente para enfrentar las complejidades que implica el restablecimiento de los derechos ${ }^{240}$.

Un asunto que domina la agenda internacional en materia de propiedad intelectual es la observancia de los derechos autorales, tanto en línea como en entornos análogos ${ }^{241}$. Para estos últimos se han propuesto diversas medidas, tales como la concesión de facultades para actuar de oficio por autoridades aduaneras y de persecución penal, la ampliación de las medidas en frontera, la mejora de

de una obra para fines educacionales); y artículos 45-71 Ley 23 de 1982 sobre derechos de autor, Diario Oficial, 19 de febrero 1982 (Colombia) (estableciendo una detallada regulación de licencias obligatorias para traducción y/o reproducción de obras desde idiomas extranjeros al castellano).

${ }^{238}$ La existencia de diferentes plazos de protección entre los países miembros de la Comunidad Andina suscita el inconveniente de que legítimos bienes disponibles en el dominio público en alguno de los países de la Comunidad no pueden entrar en el mercado de otro país sin la autorización del respectivo titular cuyos derechos se encuentran vigentes en este último país. En consecuencia, las diferencias en los plazos de protección de los derechos autorales crea barreras artificiales que entorpecen el libre flujo de bienes protegidos por los derechos de autor, así como de servicios.

${ }^{239}$ Véase supra notas 158-160 y el texto que las acompaña.

${ }^{240}$ Véase, e.g., 17 U.S.C. § 104 A (2006) (adoptando un procedimiento para el restablecimiento de derechos de autor en obras extranjeras con más flexibilidades y medidas de resguardo para terceros que aquél previsto en el régimen común).

241 Muñoz Tellez, Viviana, "The Changing Global Governance of Intellectual Property Enforcement: a New Challenge for Developing Countries", en LI, Xuan; Correa, Carlos (Ed.), Intellectual Property Enforcement: International Perspective, Edward Elgar Publishing Limited, 2009, pp. 3-13. 
los procedimientos judiciales y la adopción de daños estatutarios, entre otras ${ }^{242}$. Para entornos en línea, los principales temas continúan siendo la regulación de las medidas de protección tecnológica y el régimen de responsabilidad de los prestadores de servicios en línea ${ }^{243}$. Estos temas han sido incluidos en tratados bilaterales ${ }^{244}$. y también en recientes iniciativas internacionales, tales como el Anti-Counterfeiting Trade Agreement ${ }^{245}$ y el Trans-Pacific Partnership ${ }^{246}$. La Comunidad Andina debería adoptar un más detallado régimen común acerca de la observancia de los derechos de autor, a efectos de definir los compromisos entre los países que integran la Comunidad, así como con terceros países. Un marco legal sobre la observancia de los derechos no debería limitarse a proteger a los titulares de derechos, sino también a los usuarios e intermediarios, por ejemplo, estableciendo limitaciones al uso de medidas contractuales o tecnológicas que menoscaban los derechos de los consumidores. Además, el régimen común debe ejercer una observancia razonable, adecuando sus compromisos internacionales en la materia, así como la regulación de los derechos de autor en general, a los intereses reales de la Comunidad Andina y su población ${ }^{247}$.

En adición a los temas que deberían se incluidos en una versión actualizada del régimen común sobre derechos de autor de la Comunidad Andina, parece necesario sacar ventaja de los casi 20 años de experiencia del actual régimen común, a efectos de definir la política del siguiente paso en el proceso de convergencia normativa en la materia.

La Decisión armonizó hasta cierto punto el derecho interno de los países miembros de la Comunidad Andina adoptando estándares mínimos, pero dejando abierta la oportunidad para que a través de derecho interno los países incrementasen dichos estándares ${ }^{248}$. En los años precedentes, como se ha mencionado, los países de la Comunidad adoptaron normas sobre el régimen común mediante, por ejemplo, la extensión de los plazos de protección, de

\footnotetext{
${ }^{242}$ Véase Roffe y SANTA Cruz, Los derechos, cit. nota n. 197, p. 43.

243 Ibídem.

244 Véase, e.g., U.S. Trade Representative, Free Trade Agreements, disponible En: http://www.ustr.gov/ trade-agreements/free-trade-agreements [visitado el 20/07/2011].

245 Anti-Counterfeiting Trade Agreement. Disponible en el sitio web de la Comisión Europea: http:// trade.ec.europa.eu/doclib/html/147937.htm [visitado el 22/07/2011].

246 Véase TPP, cit. nota n. 173.

$247 \mathrm{LI}$, Xuan, "Ten General Misconceptions about the Enforcement of Intellectual Property Rights", en Lı, Xuan; Correa, Carlos (Ed.), Intellectual Property Enforcement: International Perspective, Edward Elgar Publishing Limited, 2009, pp. 40-41 (concluyendo que la agenda de observancia de los derechos de propiedad intelectual impulsada por los países desarrollados ha causado severos efectos en los países en desarrollo, los que, en cambio, deberían trabajar en maximizar las políticas pro desarrollo de sus países).

${ }^{248}$ Véase supra notas 32-35 y el texto que las acompaña.
} 
los derechos económicos, de las excepciones y limitaciones, de los casos de dominio público, y la inclusión de normas sobre observancia de los derechos en el entorno en línea. Como resultado, tras algunos años en vigencia, los desafíos para la armonización de los derechos de autor en la Comunidad Andina se han multiplicado en vez de reducirse. Un nuevo paso en la convergencia normativa en materia de derechos autorales debe adoptar no sólo estándares mínimos sino también máximos, a efectos de evitar la fragmentación del régimen común por el derecho interno de los países miembros. Por ejemplo, el régimen común debería adoptar una regulación uniforme de los plazos de protección en vez de los diferentes plazos actualmente vigentes en los países de la Comunidad Andina.

¿Significa esto que un nuevo régimen común debe prohibir cualquier regulación adicional a nivel del derecho interno? Por ahora, los legislativos nacionales son significativamente libres para adoptar nuevas normas en materia de derecho de autor en derecho interno, en tanto sea consistente con el régimen común ${ }^{249}$. Sin embargo, ello no evita la adopción de normas que, a pesar de ser consistentes con el régimen común, crean o incrementan los obstáculos para el adecuado funcionamiento del mercado interno. Esto no sugiere que la Comunidad Andina debería limitar las oportunidades para cierto desarrollo normativo en el derecho interno - de hecho, en ciertas áreas tal desarrollo es esencial, tal como en derecho penal y procesal- pero debería existir un sistema de coordinación entre el proceso legislativo de derecho interno y el régimen común. Además de su consistencia con el régimen común, la Comunidad Andina debe introducir otros factores para evaluar la conveniencia de una determinada modificación al derecho interno de un país miembro, tal como el efecto económico de la medida en el funcionamiento del mercado interior y su consistencia con la política integracionista de la misma Comunidad.

Como se ha discutido previamente, la Comunidad Andina ha autorizado a sus miembros para negociar y concluir tratados con terceros países en los cuales normas sobre propiedad intelectual se han incluido ${ }^{250}$. Esta autorización ha sido fuente de nuevos compromisos que van más allá de los estándares adoptados por la Decisión 351 y que podrían obstaculizar la adopción de un nuevo régimen común. En el futuro, a efectos de preservar su propia convergencia interna, tal como la Unión Europea ha hecho, los países miembros de la Comunidad Andina debería negociar conjuntamente o, como mínimo, someter sus negociaciones a la aprobación comunitaria, a efectos de ratificar que el contenido de las negociaciones no excede el régimen común ni crea asuntos que puedan interferir con el apropiado funcionamiento del mercado interno. Esto proveería

${ }^{249}$ Véase supra nota 26 y el texto que le acompaña.

250 Véase supra notas 190-192 y el texto que las acompaña. 
algún nivel de coordinación dentro de la Comunidad Andina, particularmente cuando sus miembros enfrentan negociaciones con terceros países.

La Comunidad Andina debería tomar completa ventaja de las flexibilidades disponibles en el derecho internacional al actualizar su régimen común, tales como las disposiciones sobre licencias obligatorias previstas en el Apéndice del Convenio de Berna ${ }^{251}$. La reglas que establecen un amplio trato nacional y el restablecimiento de los derechos deberían ser derogadas mediante la adopción de normas más flexibles, de acuerdo a los estándares mínimos del Convenio de Berna ${ }^{252}$. La Comunidad Andina debería también sacar ventaja de mecanismos más flexibles disponibles en el derecho interno de otros países, incluso países desarrollados, tal como las normas sobre restablecimiento de derechos e ingeniería inversa de software disponibles en los Estados Unidos ${ }^{253}$. Desafortunadamente, la Decisión 351 no hizo esto, sino que adoptó una perspectiva ultra-proteccionista de los derechos de autor que se focaliza en proteger a los titulares de derechos y subestima otros intereses en conflicto.

\section{CONCLUSIONES}

En el proceso de integración económica de la Comunidad Andina, sus miembros han adoptado regímenes comunes en varias áreas, tales como transporte, inversión extranjera, propiedad industrial ${ }^{254}$ y propiedad intelectual. Esto último fue logrado a través de la adopción de la Decisión 351, que provee un régimen común para los derechos de autor y conexos, la que contribuyó significativamente a la convergencia de los derechos de autor entre los países miembros de la Comunidad Andina. Sin embargo, con el transcurso de los años, la eficacia del régimen común como instrumento de convergencia normativa se ha reducido a raíz de las diferencias en el derecho interno de los miembros de la

\footnotetext{
251 Véase supra nota 236.

${ }^{252}$ Véase artículos 5 (1) y 18 Convenio de Berna. Véase también World Intellectual Property OrganizaTION, Guide to the Berne Convention for the Protection of Literary and Artistic Works (Paris Act, 1971), WIPO, Ginebra, 1978, pp. 100-101.

253 Véase supra notas 79 y 98.

${ }^{254}$ Véase Decisión № 486 Régimen Común sobre Propiedad Industrial, adoptada por la Comisión del Acuerdo de Cartagena, 14 de septiembre de 2000, Gaceta Oficial de la Comunidad Andina, 19 de septiembre de 2000 (estableciendo un régimen común para patentes, modelos de utilidad, esquemas de trazado de circuitos integrados, diseños industriales, marcas comerciales, marcas colectivas, marcas de certificación, nombres comerciales, rótulos o enseñas, indicaciones geográficas y signo distintivo notoriamente conocido). Véase también Decisión № 345 Régimen Común de Protección a los Derechos de Obtentores de Variedades Vegetales, adoptada por la Comisión del Acuerdo de Cartagena, 21 de octubre de 1993, Gaceta Oficial de la Comunidad Andina № 142, 29 de octubre de 1993, y Decisión № 391 Régimen Común sobre Acceso a Recursos Genéticos, adoptada por la Comisión del Acuerdo de Cartagena, 2 de julio de 1996, Gaceta Oficial de la Comunidad Andina № 213, 17 de julio de 1996.
} 
Comunidad, los desafíos de las nuevas tecnologías, y el emergente bilateralismo, entre otras causas. Estas circunstancias hacen explícita la necesidad de actualizar el régimen común, antes de que la falta de convergencia se transforme en un serio obstáculo para la integración de la Comunidad Andina, al obstruir el adecuado funcionamiento del mercado interno, particularmente en el contexto de la economía de la información.

Un nuevo régimen común para la Comunidad Andina debería hacer progresar la agenda de sus propios miembros antes que la de terceros países, anticipando y superando los obstáculos para la futura integración económica de sus miembros. Este nuevo régimen común, a diferencia de la Decisión 351, no debería tener una énfasis meramente proteccionista, sino que debería incluir disposiciones en favor de autores, usuarios e intermediarios. En particular, teniendo en consideración los temas que suscitan problemas para el adecuado funcionamiento del mercado interno, el nuevo régimen común debería armonizar disposiciones en relación a la extensión de los derechos de autor, limitaciones y excepciones, dominio público y observancia de los derechos de propiedad intelectual.

Adicionalmente, si la Comunidad Andina desea preservar y enfatizar la convergencia de su mercado interno, los países miembros deben comprometerse a uniformar sus estándares; adoptar mecanismos de coordinación dentro de la Comunidad, así como entre sus miembros y terceros países; y tomar ventaja de las flexibilidades provistas para países en desarrollo por el derecho internacional, así como de la experiencia de otros países al proveerse de flexibilidades en su derecho interno. Un nuevo régimen común debe incrementar la convergencia normativa dentro de la Comunidad Andina, pero también con otros países.

\section{BibLiOGRAFíA}

\section{Literatura}

Antequera, Ricardo, El Nuevo Derecho de Autor en Venezuela, Autoralex, Caracas, 1994.

ANTEQUerA, Ricardo, "Copyright and Andean Community Law", Revue Internationale du Droit D'Auteur 166, 1995.

AnTEQuera, Ricardo, Derecho de Autor, $2^{\text {a }}$ Edición, Dirección Nacional del Derecho de Autor, Caracas, 1998.

Antequera, Ricardo; Ferreyros, Marysol, El Nuevo Derecho de Autor en el Perú, Peru Reporting, Lima, 1996.

Antequera, Ricardo, "El Derecho de Autor y los Derechos Conexos en la Legislación Venezolana", en Antequera, Ricardo; Gómez MuCI, Gineli, Legislación sobre Derecho de Autor y Derechos Conexos, Ed. Jurídica Venezolana, 1999. 
Braga Avancini, Helenara; Leão Barcellos, Milton Lucídio, Perspectivas Autorais do Direito da Propriedade Intelectual, EdiPUCRS, Puerto Alegre, 2009.

Brewer-Carías, Allan-Randolph (Ed.), Derecho Comunitario Andino, Fondo Editorial Pontificia Universidad Católica del Perú, Lima, 2003.

Castro García, Juan David, "El Agotamiento de los Derechos de Propiedad Intelectual", Revista la Propiedad Inmaterial № 13, 2009.

Chalders, Demian; Davies, Gareth; Monti, Giorgio, European Union Law, 2nd ed., Cambridge University Press, 2010.

Charria García, Fernando, Derecho de Autor en Colombia, Instituto Departamental de Bellas Artes, Cali, 2001.

CHON, Margaret, "Copyright and capability for education: an approach 'from below'", en Wong, Tzen; Dutfield, Graham (Ed.), Intellectual Property and Human Development: Current Trends and Future Scenarios, Cambridge University Press, 2011.

Colston, Catherine; Galloway, Jonathan, Modern Intellectual Property Law, $3^{a}$ Edicióm, Routledge, 2010.

Davies, Gareth, EU Internal Market Law, $2^{a}$ Edición, Cavendish Publishing, Londres, 2003.

DE VRIES, Sybe Alexander, Tension within the Internal Market: The Functioning of the Internal Market and the Development of Horizontal and Flanking Policies, Europa Law Publishing, Groningen, 2006.

DreIER, Thomas, "Shaping a Fair International IPR-Regime in a Globalized World. Some Parameters for Public Policy", en Govaere, Inge, Ullrich, Hanns (Eds.), InteIlectual Property, Public Policy, and International Trade, Peter Lang, Bruselas.

Fitzgerald, Anne; Fitzgerald, Brian, Intellectual Property in Principle, Lawbook Co., Sydney, 2004.

Forero, Fabio, "La Coordinación de la Política Comercial en la Comunidad Andina y su Efecto en el Proceso de Integración", Revista de la Asociación Iberoamericana de Academias, Escuelas e Institutos Diplomáticos № 1, 2010.

Fuentes, Fernando, Manual de los Derechos Intelectuales, Vadell Hermanos Editores, Caracas, 2006.

Fuentes Fernández, Alfredo, "Contexto Histórico y Avances de la Integración en la Comunidad Andina", Revista Oasis, Universidad Externado de Colombia $N^{\circ} 13,2008$.

Gómez Mucl, Gineli, "El Derecho de Autor y los Derechos Conexos en el Marco del Acuerdo sobre los Aspectos de los Derechos de Propiedad Intelectual relacionados con el Comercio, Acuerdo sobre los ADPIC", en ANTEQUERA; Gómez, Legislación sobre Derecho de Autor y Derechos Conexos, Ed. Jurídica Venezolana, Caracas, 1999. 
Gómez Velasco, Xavier, Patentes de Invención y Derecho de la Competencia Económica, Universidad Andina Simón Bolívar, Quito, 2003.

GriJalva, Agustín, "Copyright \& the Internet", en Bonilla, Marcelo; ClichÉ, Gilles (ed.), The Internet and Society in Latin America and the Caribbean, International Development Research Center, Canadá, 2004.

Helfer, Laurence R.; Alter, Karen J., "The Andean Tribunal of Justice and Its Interlocutors: Understanding Preliminary Reference Patterns in the Andean Community", New York University International Law and Politics Vol. 41 2009.

Helfer, Laurence R.; Alter, Karen J.; Guerzovich, M. Florencia, "Islands of Effective International Adjudication: Constructing an Intellectual Property Rule of Law in the Andean Community", American Journal of International Law Vol. 103, 2009.

Julià-BARCeló, Rosa, "On-line Intermediary Liability Issues: Comparing E.U. and U.S. Legal Frameworks", European Intellectual Property Review Vol. 22, $N^{\circ} 3$, 2000. Kaczorowska, Alina, European Union Law, $2^{\text {a }}$ Edición, Routledge, 2011.

Kur, Annette, "Intellectual Property", en Van Empel, Martijn, From Paris to Nice: Fifty Years of Legal Integration in Europe, Kluwer Law International, La Haya, 2003.

Leathley, Christian, International Dispute Resolution in Latin America: An Institutional Overview, Kluwer Law International, Alphen aan den Rijn, 2007.

LI, Xuan; Correa, Carlos (Ed.), Intellectual Property Enforcement: International Perspective, Edward Elgar Publishing Limited, 2009.

LIPSZYC, Delia, Copyright and Neighbouring Rights, UNESCO, París, 1999. La Conferencia de Revisión de las Convenciones de Berna y Universal (París - Julio de 1971): Enfoque Argentino, CISAC, Buenos Aires, 1975.

Lipszyc, Villalba; Uchtenhagen, La Protección de los Derechos de Autor en el Sistema Interamericano, Universidad Externado de Colombia, Dirección Nacional de Derechos de Autor, Bogotá, 1998.

MADRID, Luis Ángel, Importaciones Paralelas (Agotamiento de los Derechos de Propiedad Intelectual), Centro Colombiano del Derecho de Autor, 2005.

MuÑoz Tellez, Viviana, "The Changing Global Governance of Intellectual Property Enforcement: a New Challenge for Developing Countries", en Lı, Xuan y Correa, Carlos (Ed.), Intellectual Property Enforcement: International Perspective, Edward Elgar Publishing Limited, 2009.

Nic SHuibhne, Niamh (Ed.), Regulating the Internal Market, Edward Elgar Publishing, Cheltenham, 2006. 
O'Keefe, Thomas Andrew, "How the Andean Pact Transformed Itself into a Friend of Foreign Enterprise", International Lawyer Vol. 30.

O'KeEFe, Thomas Andrew, "Latin American and Caribbean Trade Agreements: Keys to a Prosperous Community of the Americas", Martinus Nijhoff Publishers, Países Bajos, 2009.

Parga, César, "Intellectual Property Rights", en Salazar Xirinachs, Jose Manuel: ROBERT, Maryse (Ed.), Toward Free Trade in the Americas, Washington, DC, USA: Brookings Institution Press, 2001.

PACón, Ana María, "La Protección del Derecho de Autor en la Comunidad Andina", en Brewer-Carías, Allan-Randolph (Ed.), Derecho Comunitario Andino, Fondo Editorial Pontificia Universidad Católica del Perú, Lima, 2003.

Rodriguez Lemmo, María Alejandra, "Study of Selected International Dispute Resolution Regimes, with an Analysis of the Decisions of the Court of Justice of the Andean Community", Arizona Journal of International and Comparative Law Vol. 19, 2000.

Rodríguez Moreno, Sofía, Era Digital y las Excepciones y Limitaciones al Derecho de Autor, Universidad Externado de Colombia, 2004.

Rodrícuez Ruiz, Marco, Los Nuevos Desafíos de los Derechos de Autor en Ecuador, Universidad Andina Simón Bolívar, Quito, 2007.

Rodríguez Yong, Camilo A., "Enhancing Legal Certainty in Colombia: the Role of the Andean Community", Michigan State Journal of International Law Vol. 17, 2008-2009.

Roffe, Pedro; Santa Cruz, Maximiliano, Los derechos de propiedad intelectual en los acuerdos de libre comercio celebrados por países de América Latina con países desarrollados, Serie Comercio Internacional, Comisión Económica para América Latina y el Caribe, CEPAL, 2006.

Rogers, Thomas; Szamosszegl, Andrew, Fair Use in the U.S. Economy: Economic Contribution of Industries Relying on Fair Use, CCIA, Washington D.C., 2011.

Rondón de SAnsó, Hildegard, El Régimen de la Propiedad Industrial, Caracas, 1995.

Salones Gaite, Ana María, La Propiedad Intelectual en Bolivia: Marco Conceptual, Jurídico e Institucional, 2003.

Scott, Andrew, "Theories of Regional Economic Integration and the Gloval Economy", en Jackie Gower (Ed.), The European Union Handbook, $2^{a}$ Edición, Fitzroy Dearborn Publishers, 2002.

SHERWOOD, Robert, Intellectual Property and Economic Development, Westview Press, 1990. 
Taccone, Juan José; Nogueira, Uziel (Eds.), Andean Report 2002-2004, Institute for the Integration of Latin America and the Caribbean (INTAL), IDB-INTAL, Buenos Aires, 2005.

Tremolada Álvarez, Eric, "El Derecho Andino: Una Sistematización Jurídica para la Supervivencia de la Comunidad Andina de Naciones", Cuadernos Constitucionales de la Cátedra Fadrique Furió Ceriol № 57, Universidad de Valencia.

United Nations Conference on Trade and Development (UNCTAD) and the International Centre for Trade and Sustainable Development (ICTSD), Resource Book on TRIPS and Development, Cambridge University Press, 2005.

Vásquez Santamaría, Jorge Eduardo, "El Agotamiento del Derecho de Marca", Opinión Jurídica julio-dic., año/vol. 6, num. 12, Universidad de Medellín, 2007.

Vega Jaramillo, Alfredo, Manual de Derecho de Autor, Dirección Nacional de Derecho de Autor, Bogotá, 2010.

Vela Orbegozo, Bernardo, "La Integración Regional como un Factor de Desarrollo Nacional", en Reformas y Políticas en Colombia y América Latina, Universidad Externado de Colombia - CIPE, 2003.

Villalba, Carlos, "Duración de la Protección y Excepciones", en Anais do Seminário Internacional sobre Direitos Autorais, Editora da Universidade do Vale do Rio dos Sinos, São Leopoldo, 1994.

World Intellectual Property Organization, Alcance y Limitaciones de los Derechos de Propiedad Industrial, OMPI/PI/SEM/BOG/02/1, 1 de julio de 2002, en Seminario de la OMPI para los Países Andinos sobre la Observancia de los Derechos de Propiedad Intelectual en Frontera, 10 al 11 de julio de 2002.

World Intellectual Property Organization - Standing Committee on Copyright and Related Rights, Study on Copyright Limitations and Exceptions for the Visually Impaired (prepared by Judith Sullivan), SCCR/15/7, Feb. 20, 2007.

World Intellectual Property Organization (WIPO), Scoping Study on Copyright and Related Rights and the Public Domain (prepared by Séverine Dusollier), CDIP/4/3/REV./STUDY/INF/1, May 7, 2010.

World Trade Organization, Trade Policy Review Body, Trade Policy Review Ecuador, Report by the Secretariat - Revision, WT/TPR/S/148/Rev.1, 25 July 2005.

World Trade Organization, Trade Policy Review Body, Trade Policy Review, Report by the Secretariat - Bolivia, WT/TPR/S/154, 4 Oct. 2005.

World Trade Organization, Trade Policy Review Body, Trade Policy Review, Report by the Secretariat - Colombia, WT/TPR/S/172, 18 Oct. 2006.

World Trade Organization, Trade Policy Review Body, Trade Policy Review, Report by the Secretariat - Peru, WT/TPR/S/189, 12 Sep. 2007. 
XUE, Hong, "Enforcement for Development: Why not an Agenda for the Developing World?", en LI, Xuan; CorreA, Carlos (Ed.), Intellectual Property Enforcement: International Perspective, 2009, Edward Elgar Publishing Limited.

Yu, Peter, "TRIPS and Its Discontents", Marquette Intellectual Property Law Review Vol. 10, 2006.

\section{Derecho Internacional}

Acuerdo Comercial Anti-Falsificación (versión no oficial en español, de 3 de diciembre de 2010). Disponible En: http://www.impi.gob.mx/work/sites/ IMPI/resources/LocalContent/2361/32/Acuerdo_ACTA_3_Dic_2010_no_oficial_es.pdf [visitado el 13/07/2011].

Acuerdo de Cartagena, Bogotá, de 28 de mayo de 1969.

Acuerdo sobre los Aspectos de los Derechos de Propiedad Intelectual relacionados con el Comercio (ADPIC), 15 de abril de 1994, Acuerdo de Marrakesh que establece la Organización Mundial de Comercio, Anexo 1C, 1869 U.N.T.S. 299.

Convención Interamericana sobre el Derecho de Autor en Obras Literarias, Científicas y Artísticas, adoptada en Washington D.C., el 22 de junio de 1946.

Convención Universal sobre Derecho de Autor. Ginebra, 6 de septiembre de 1952.

Convenio de Berna para la Protección de las Obras Literarias y Artísticas, Acta de París de 24 julio de 1971 y enmendado el 28 de septiembre de 1979.

Decisión № 351 Régimen Común sobre Derecho de Autor y Derechos Conexos, adoptada por la Comisión del Acuerdo de Cartagena, 17 de diciembre de 1993, Gaceta Oficial de la Comunidad Andina, № 145, 21 de diciembre de 1993.

Decisión № 486 Régimen Común sobre Propiedad Industrial, adoptada por la Comisión del Acuerdo de Cartagena, 14 de septiembre de 2000, Gaceta Oficial de la Comunidad Andina, 19 de septiembre de 2000.

Decisión № 598 Relaciones comerciales con terceros países, adoptada por la Comisión del Acuerdo de Cartagena, 11 de julio de 2004, Gaceta Oficial de la Comunidad Andina, No 1092, 6 de julio de 2004.

Declaración Universal de Derechos Humanos, adoptado por la Asamblea General de las Naciones Unidas en su Resolución Res. 217 (III) A, de 10 de diciembre de 1948.

Propuesta del Brasil, el Ecuador y el Paraguay en relación la limitaciones y excepciones: Propuesta de tratado de la Unión Mundial de Ciegos (UMC), Documento OMPI, SCCR/18/5, 25 de mayo de 2009. En: www.wipo.int/ edocs/mdocs/copyright/es/sccr_18/sccr_18_5.doc [visitado el 13/06/2011] 
Trans-Pacific Partnership - Intellectual Property Rights Chapter: Draft - Feb. 10, 2011 (versión no oficial). Disponible en: http://keionline.org/sites/default/ files/tpp-10feb2011-us- text-ipr-chapter.pdf [visitado el 13/07/2011]

Tratado constitutivo de la Unión de Naciones Suramericanas, hecho en Brasilia - Brasil, el 23 de mayo de 2008.

Tratado de Funcionamiento de la Unión Europea, Diario Oficial de la Unión Europea, 30 de marzo de 2010.

Tratado de la OMPI sobre Derecho de Autor, adoptado en Ginebra el 20 de diciembre de 1996.

Tratado de la OMPI sobre Interpretación o Ejecución y Fonogramas, adoptado en Ginebra el 20 de diciembre de 1996.

Tratado de Libre Comercio Colombia - Estados Unidos, suscrito el 22 de noviembre de 2006. Disponible en: http://www.tlc.gov.co/ [visitado el 19/07/2011].

Tratado de Libre Comercio Perú - Estados Unidos, suscrito el 12 de abril de 2006. Disponible en: www.tlcperu-eeuu.gob.pe/ [visitado el 19/07/2011].

\section{Derecho Interno}

Decreto $N^{\circ} 1360$ de 23 de junio de 1989: Por el cual se reglamenta la inscripción del soporte lógico (software) en el Registro Nacional del Derecho de Autor, Diario Oficial, 21 de marzo de 1995 (Colombia).

Decreto Legislativo No 822: Ley sobre Derechos de Autor, Diario Oficial, 24 de abril de 1996 (Perú).

Decreto Supremo № 24582 del 25 de abril de 1997: Reglamento del Soporte Lógico o Software (Bolivia).

Ley No 1322 de 1992: Ley de Derecho de Autor, Gaceta Oficial, 27 de abril de 1992 (Bolivia).

Ley № 17.336 sobre Propiedad Intelectual, modificada por la Ley № 20.435, Diario Oficial, 4 de mayo de 2010 (Chile).

Ley de Propiedad Intelectual, codificación 2006-013, Boletín Oficial, 19 de mayo de 1998 (Ecuador).

Ley N ${ }^{\circ} 23$ de 1982 sobre Derechos de Autor, Diario Oficial, 19 de febrero 1982 (Colombia).

Title 17 of the United States Code [U.S. Copyright Act]. 


\section{ANEXO}

\section{Tabla 1}

Comunidad Andina de Naciones, acuerdos internacionales sobre derechos de autor en que sus miembros son partes

\begin{tabular}{l|c|c|c|c|c|c} 
& $\begin{array}{c}\text { Convención } \\
\text { Interamericana } \\
(1)\end{array}$ & $\begin{array}{c}\text { Convención } \\
\text { Universal } \\
(2)\end{array}$ & $\begin{array}{c}\text { Convenio } \\
\text { de Berna } \\
(3)\end{array}$ & $\begin{array}{c}\text { Acuerdo } \\
\text { sobre } \\
\text { los } \\
\text { ADPIC }\end{array}$ & $\begin{array}{c}\text { Tratado } \\
\text { OMPI } \\
\text { Derechos } \\
\text { de Autor (4) }\end{array}$ & $\begin{array}{c}\text { Tratado OMPI } \\
\text { Interpretación } \\
\text { o Ejecución y } \\
\text { Fonogramas (5) }\end{array}$ \\
\hline Bolivia & 1947 & 1989 & 1993 & 1995 & - & - \\
\hline Colombia & 1976 & 1976 & 1987 & 1995 & 2000 & 2000 \\
\hline Ecuador & 1947 & 1957 & 1991 & 1996 & 2000 & 2000 \\
\hline Perú & - & 1963 & 1988 & 1995 & 2001 & 2002 \\
\hline Venezuela & - & 1966 & 1982 & 1995 & - & -
\end{tabular}

Notes: (1) Ratificación, OEA; (2) Ratificación, UNESCO; (3) Accesión, OMPI;

(4) Ratificación/Accesión, OMPI; (5) Ratificación/Accesión, OMPI. 